\title{
Eco-Friendly ZnO/Chitosan Bionanocomposites Films for Packaging of Fresh Poultry Meat
}

\author{
Victor Gomes Lauriano Souza ${ }^{1, *}$,, Carolina Rodrigues ${ }^{1}$, Sara Valente ${ }^{1}$, Catarina Pimenta ${ }^{1}$,

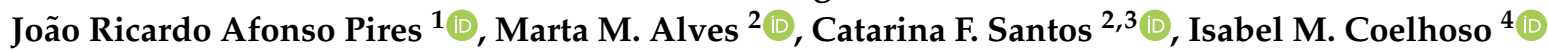 \\ and Ana Luísa Fernando $1, *$ (D) \\ 1 MEtRICs, Departamento de Ciências e Tecnologia da Biomassa, Faculdade de Ciências e Tecnologia, \\ Universidade NOVA de Lisboa, Campus de Caparica, 2829-516 Caparica, Portugal; \\ cpe.rodrigues@campus.fct.unl.pt (C.R.); sa.valente@campus.fct.unl.pt (S.V.); \\ cr.pimenta@campus.fct.unl.pt (C.P.); jr.pires@campus.fct.unl.pt (J.R.A.P.) \\ 2 CQE Instituto Superior Técnico, Universidade de Lisboa, Av. Rovisco Pais, 1049-001 Lisboa, Portugal; \\ martamalves@tecnico.ulisboa.pt (M.M.A.); catarina.santos@estsetubal.ips.pt (C.F.S.) \\ 3 EST Setúbal, CDP2T, Instituto Politécnico de Setúbal, Campus IPS, 2910 Setúbal, Portugal \\ 4 LAQV-REQUIMTE, Departamento de Química, Faculdade de Ciências e Tecnologia, Universidade Nova de \\ Lisboa, Campus de Caparica, 2829-516 Caparica, Portugal; imrc@fct.unl.pt \\ * Correspondence: v.souza@campus.fct.unl.pt (V.G.L.S.); ala@fct.unl.pt (A.L.F.); \\ Tel./Fax: +351-212948543 (A.L.F.)
}

Received: 19 December 2019; Accepted: 25 January 2020; Published: 28 January 2020

\begin{abstract}
The advances on the development of novel materials capable to enhance the shelf life of food products may contribute to reduce the current worldwide food waste problem. Zinc oxide nanoparticles (ZnO NPs) are considered GRAS (Generally Recognized as Safe) by the Food and Drug Administration (FDA) and due to their good antimicrobial properties are suitable to be applied as active compounds in food packaging. ZnO NPs were synthesized to be tested in active bionanocomposites through an eco-friendlier route using apple peel wastes. This work aimed to develop bionanocomposites based on chitosan and incorporated with ZnO NPs to characterize its bioactivity via in vitro and in situ studies, using fresh poultry meat as the food matrix. Overall, bio-based biodegradable films presented good antimicrobial activity, being the intrinsic antimicrobial properties of chitosan enhanced by the ZnO NPs added on the system. When used as primary packaging of the meat, the samples protected with the films presented a decrease on the deterioration speed, which was represented by the preservation of the initial reddish color of the meat and reduction on the oxidation process and microbiological growth. The nanoparticles enhanced especially the antioxidant properties of the films and proved to be potential food preservatives agents to be used in active food packaging.
\end{abstract}

Keywords: active packaging; biodegradable material; shelf-life extension; antimicrobial activity; antioxidant activity; zinc oxide nanoparticles

\section{Introduction}

Food waste represents a considerable inefficiency of the global food system and contributes to environmental pollution and resources depletion. Within the United Nations Sustainable Development Goal 12.3, countries are committed to reduce by 50\% food waste along the food supply chain by 2030 [1]. It is recognized that shelf-life extension plays a key role in reducing food waste. Thus, packaging should improve the balance between the environmental impact of the package itself and the impact deriving from the potential loss of the food product, which is strictly related to its shelf life [2]. In this context, the use of non-biodegradable plastics should be replaced by biodegradable and renewable 
packaging, with improved active properties, such as antimicrobial and antioxidant activities, capable to protect the food packaged, extending its shelf life [3-6].

A high variety of polysaccharides and their derivatives have been used to produce biodegradable films. Polysaccharides are the most abundant macromolecules in the biosphere (cellulose, chitin, and starch) [7]. Chitosan (poly- $\beta(1,4)$-2-amino-2-deoxy-D-glucopyranose), obtained by deacetylation of chitin, is one of the biopolymers most used due to its antimicrobial properties [8-11]. In order to improve mechanical and barrier properties to water and gases, nanocomposites are being employed. Montmorillonite (MMT), a layered silicate mineral clay, is a highly used nanomaterial due to its low cost, abundancy, mechanical resistance, swelling, and plasticizer ability [12,13]. Other nanofillers, such as nanocellulose, are also an attractive option due to their high compatibility with chitosan $[14,15]$. However, it is still not fully understood whether these nanomaterials may pose a risk to the consumers or to the environment after their disposal. The risk assessment of nanoparticles (NPs) is challenging, mainly due to the scarce availability of suitable analytical techniques to detect and to characterize either in the food and beverage matrices or into the environment [16]. The reduction in size may also change their toxicity and the existing toxicological studies are not conclusive. For instance, non-modified montmorillonite has not shown cytotoxic or mutagenic effect while modified MMT did. The same inconclusive answers were obtained with silver nanoparticles, the most used NPs in food products [16].

Nanometal oxides are also an interesting solution once their incorporation contributes to improve the antimicrobial, UV blocking, and magnetic properties of the biopolymers along with their reinforcing capacity $[17,18]$. Due to their high aspect ratio (relationship between the length and the width of the particles, i.e., the surface to volume ratio of nanoparticles) and the most economical properties, metallic nanoparticles and metal oxide nanoparticles present strong antibacterial activity at low concentrations. Silver, gold, copper, titanium oxide, and zinc oxide are some of the common nanoparticle studied [19-21]. According to Chaudhry et al. (2008) [22], food packaging materials' (FPMs') development is currently the largest category of nanotechnology application in the food sector. The incorporation of ZnO NPs in FPMs aims to provide the material with antimicrobial activity, while it may play an important role on the improvement of packaging properties, such as mechanical strength, barrier properties, and thermal stability [20]. Zinc oxide $(\mathrm{ZnO})$ is a noteworthy alternative due to its antimicrobial and antifungal properties and because it is Generally Recognized as Safe (GRAS) by the Food and Drug Administration (FDA). In the European Union, a study made by EFSA (European Food Safety Authority) on the safety of $\mathrm{ZnO}$ NPs, for use in food contact materials, recommended that the Commission should impose an upper limit of zinc of $25 \mathrm{mg} /$ person per day. It was also concluded that the substance does not migrate in nanoform and, therefore, the safety evaluation should focus on the migration of soluble ionic zinc [23].

$\mathrm{ZnO}$ nanoparticles ( $\mathrm{ZnO} \mathrm{NPs}$ ) can be synthesized by physical or chemical methods [24]. From those, when targeting food packaging applications, chemical synthesis assisted by natural compounds is the most economical and safe synthesis route [25]. From the wide range of phytochemical available in nature, plant phytochemicals intrinsically targeted for antimicrobial purposes, as those present in fruit peels, can potentiate $\mathrm{ZnO}$ antimicrobial effects. From the phytochemical peels used for $\mathrm{ZnO}$ NPs synthesis [26,27], the use of commercial apples rendered the synthesis of economically viable, antimicrobial, and nontoxic ZnO NPs [28], with potential to be used in food-packaging applications.

Several authors have reported the use of ZnO NPs in biopolymer composites for active food packaging with the aim to reduce the growth of pathogenic bacterial and extend food shelf life [29-33]. In some cases, $\mathrm{ZnO}$ NPs were used with essential oils to reinforce the antimicrobial properties of the active films. A composite film incorporating $\mathrm{ZnO}$ nanorods and clove essential oil (CEO) was prepared with bovine skin gelatin as the polymer matrix. Composite films loaded with 50\% CEO, in combination with ZnO NPs, showed maximum antibacterial activity against Listeria monocytogenes and Salmonella Typhimurium inoculated in shrimp during refrigerated storage $[34,35]$. However, in all cases ZnO NPs employed were commercial and not obtained by eco-friendly methods. 
The aim of this work was to develop nanocomposites based on chitosan and ZnO NPs, which were produced for the first time with the Golden Delicious apple variety, obtained using food-grade industrial waste, i.e., apple peel. This novel approach under the umbrella concept of circular economy [36,37] can minimize waste generation, thus decoupling economic growth from natural resources as new raw materials to develop high value-added products that can be used as primary packaging for fresh poultry meat. Thus, the work will have a dual purpose: The eco-friendly synthesis of ZnO NPs through the use of apple peel extracts, using and adding value to a residue, and their incorporation in chitosan films, to evaluate their antioxidant and antimicrobial properties in poultry meat shelf life, and, therefore, contributing to the circular bioeconomy concept.

\section{Materials and Methods}

\subsection{Materials and Reagents}

All reagents used were with analytical reagents grade and the water used was purified using Milli-Q system (Millipore, Billerica, MA, USA). Chitosan with high molecular weight (31-37 $\mathrm{kDa})$ and $75 \%$ of deacetylation, ethanol absolute, potassium hydroxide, zinc nitrate hexahydrate, and 1,1,3,3-tetraethoxypropane (TEP) were acquired from Sigma-Aldrich (Steinheim, Germany). Glacial acetic acid, glycerol, and sodium hydroxide $(\mathrm{NaOH})$ were purchased from Alfa Aesar (Kandel, Germany), while sodium chloride ( $\mathrm{NaCl}$ ), 2-thiobarbituric acid (TBA), nitric acid, sodium carbonate anhydrous, and trichloroacetic acid (TCA) was obtained from PanReac (Barcelona, Spain). All microbiological reagents were purchased from Biokar (Allonne, Beauvais, France): Violet red bile glucose (VRBG), triptic soy broth (TSB), triptic soy agar (TSA), tryptone, plate count agar (PCA), and Mueller-Hinton agar (MHA). All chemicals are of analytical reagent grade and were used as purchased.

\subsection{Zinc Oxide Nanoparticle Synthesis}

For the preparation of the apple extract a commercial apple (Malus domestica) variety Golden Delicious was used. To ensure minimal variation from batch-to-batch extract production, only apples at commercial maturity were selected [38]. The eco-friendly synthesis was performed as previously described for another apple variety [28]. Briefly, $0.2 \mathrm{~g}$ of fresh weight (FW) of peels were boiled in $1 \mathrm{~mL}$ of water for $20 \mathrm{~min}$. The resulting extract was filtered with gauze followed by a Whatmann No. 1 filter. For the NPs' synthesis, zinc nitrate $2 \%$ (weight/volume) was added to the extract followed by potassium hydroxide $(\mathrm{KOH}) 1 \mathrm{M}(1: 6$ (volume/volume)). The synthesized ZnO NPs (Figure S1) were filtered with a PM UC500 membrane (Microdyn Nadir, Wiesbaden, Germany) and dried overnight in a conventional oven (WTB binder, Germany) at $70^{\circ} \mathrm{C}$. The characterization made by X-ray diffraction (XRD) and scanning electron microscopy (SEM) (please see Supplementary Material) showed that the $\mathrm{ZnO}$ crystalline nanoparticles were well individualized, spherical-like shape, with sizes around $100 \mathrm{~nm}$. Moreover, their nontoxicity was already proven against fibroblast cells [28].

\subsection{Bionanocomposites Production}

Bionanocomposites were produced according to Souza et al. (2017) [39] with modifications. To prepare the film-forming dispersion (FFD), 1.5\% (weight/volume) of chitosan was dissolved in $1 \%(\mathrm{v} / \mathrm{v})$ of glacial acetic acid solution under continuous agitation overnight at room temperature. Then, 30\% (w/w chitosan) of glycerol, plasticizer, and ZnO NPs at the levels used $(0.5 \%, 1 \%$, or $2 \%$ weight/weight of chitosan) were incorporated. Subsequently, a stirring cycle consisting of 5 min agitation with Ultra-Turrax $(15,000 \mathrm{rpm})\left(\mathrm{IKA}{ }^{\circledR} \mathrm{T} 18\right.$, Staufen, Germany) followed by $15 \mathrm{~min}$ degasification in ultrasound bath (360 Watt) (Selecta, Spain) was carried out. Finally, the resulting dispersion was casted in glass molds $(18 \mathrm{~cm} \times 25 \mathrm{~cm})$ and let to dry at room temperature for approximately $48-72 \mathrm{~h}$. A control film without the nanoparticles (pristine chitosan film) was also prepared. 


\subsection{In Vitro Antimicrobial Characterization of $\mathrm{ZnO} N P$ and Bionanocomposites}

The nanoparticles' antimicrobial activity was assessed by disk diffusion test [40,41] against Gram-positive Staphylococcus aureus (ATCC ${ }^{\circledR} 6538^{\mathrm{TM}}$ ) and Gram-negative Escherichia coli (ATCC ${ }^{\circledR}$ $\left.8739^{\mathrm{TM}}\right)$ foodborne bacteria. Briefly, a Petri dish $(8.5 \mathrm{~cm}$ of diameter) containing sterilized Mueller-Hinton agar (MHA) was inoculated with a suspension and spread with a sterile swab throughout the Petri dish, containing $1.5 \times 10^{8} \mathrm{CFU}$ (colony-forming unit)/mL of each bacteria (adjusted to match a 0.5 McFarland turbidity standard using a McFarland densitometer, Model Den-1B, Grant Instruments, Cambridge, UK) [41]. Wells with 6-mm diameter were cut in the MHA and filled with $50 \mu \mathrm{L}$ of $\mathrm{ZnO}$ NP in different concentrations in water, namely: 100, 150, and $200 \mathrm{mg} / \mathrm{mL}$. Sterilized water was used as negative control. Prior to the incubation at $37^{\circ} \mathrm{C}$ for $20 \mathrm{~h}$, the plates were maintained refrigerated $\left(4^{\circ} \mathrm{C}\right)$ for $2 \mathrm{~h}$ to enable the diffusion of the active compounds before the starting of the bacteria growth. Inhibition zone (diameter) was measured and the results expressed in $\mathrm{mm}$.

In vitro antimicrobial activity of the bionanocomposites was studied by viable cell colony count (CFU) method [11] against the same foodborne bacteria. Briefly, $0.2 \mathrm{~g}$ of each film was immersed in $4 \mathrm{~mL}$ of TSB containing $\sim 10^{6} \mathrm{CFU} / \mathrm{mL}$ of the tested bacteria (previously adjusted to match a 0.5 McFarland turbidity standard using a McFarland densitometer and then diluted 100 times to reach this concentration). In those tests, the concentration of NPs tested was $0.25-1 \mathrm{mg} / \mathrm{mL}$, much lower than the concentrations tested with pristine NPs. Subsequently, the tubes were kept shaking (150 rpm) incubated at $37^{\circ} \mathrm{C}$ for $24 \mathrm{~h}$. Tubes without films were used as blank and tubes with pristine chitosan film as control. From the serial dilutions, samples were plated on TSA and incubated for 16-24 h at the same temperature, and the number of viable microorganism colonies was counted. Results were expressed as the number of log reductions calculated according to Equation (1):

$$
\text { number of } \log \text { reductions }=\log \mathrm{B}-\log \mathrm{A}
$$

where $\mathrm{B}$ and $\mathrm{A}$ are the mean number of bacteria $(\mathrm{CFU} / \mathrm{mL})$ in the blank tubes and treated samples after $24 \mathrm{~h}$ incubation, respectively.

\subsection{Application in Fresh Poultry Meat}

The films produced were used to package fresh poultry minced meat purchased at a local market. The samples (approximately $30 \mathrm{~g}$ of meat) were wrapped on films specimens $(5 \mathrm{~cm} \times 18 \mathrm{~cm})$ and stored in plastic boxes with screw caps, under refrigeration $\left(5 \pm 2{ }^{\circ} \mathrm{C}\right)$ for 11 days. Unwrapped meat was used as control, and the experiment was performed in triplicate. Periodically (storage days $0,2,4,7$, and 11), meat was characterized according to the following methods.

\subsubsection{Physicochemical Characterization and Thiobarbituric Acid Reactive Substances (TBARS) Index}

Physicochemical characterization was evaluated in terms of $\mathrm{pH}$, titratable acidity, total volatile basic nitrogen (TVB-N), and moisture according to AOAC (Association of Official Analytical Chemists) method [42].

Meat color was measured on the surface of the samples through the determination of the CIE (International Commission on Illumination)-L* $\mathrm{a}^{*} \mathrm{~b}^{*}$ coordinates, where $\mathrm{L}=0$ (black) to $\mathrm{L}=100$ (white), $-\mathrm{a}$ (greenness) to $+\mathrm{a}$ (redness), and $-\mathrm{b}$ (blueness) to $+\mathrm{b}$ (yellowness) using a CR 410 colorimeter (Minolta Co., Tokyo, Japan) with D65 light source, and visual angle of $10^{\circ}$. Hue angle was calculated according to Equation (2) [6]:

$$
\text { Hue angle }=\tan (b / a)^{-1}
$$

where $\mathrm{b}^{*}$ and $\mathrm{a}^{*}$ are the coordinates measured from the samples.

TBARS were used to monitor the lipid oxidation. To extract the malonaldehyde (MDA), first, 10 grams of each sample were mixed with $20 \mathrm{~mL}$ of TCA $7.5 \%$ (weight/volume), agitated for $30 \mathrm{~min}$ and then filtrated. Subsequently, $5 \mathrm{~mL}$ of the filtrate was combined with $5 \mathrm{~mL}$ of TBA $0.02 \mathrm{M}$ and heated 
( $95^{\circ} \mathrm{C} / 30 \mathrm{~min}$ ) in water bath (Memmert, Büchenbach, Germany). After cooling, the absorbance was measured at $530 \mathrm{~nm}$ in UV/VIS spectrophotometer (Spekol 1500, Analytikjena, Germany). Calibration curve using known concentrations of MDA (from TEP solution) was used to calculate the TBARS index. Results were expressed as mg of MDA/kg of meat [8].

\subsubsection{Microbiological Growth}

Total mesophilic aerobic microorganism (TMAM), total psychrotrophic aerobic microorganism (TPAM), and Enterobacteriaceae were measured to assess the microbiological quality of the meat packaged, according to ISO 4833-1:2013 [43], ISO 17410:2019 [44], and ISO 21528-2:2017 [45], respectively. Total mesophilic aerobic bacteria and TPAM counts were performed in PCA after incubation at $30^{\circ} \mathrm{C}$ for $72 \mathrm{~h}$ or $7{ }^{\circ} \mathrm{C}$ for $168 \mathrm{~h}$. Enterobacteriaceae were performed in VRBG agar after incubation at $30^{\circ} \mathrm{C}$ for $24 \mathrm{~h}$. Results were expressed as $\log \mathrm{CFU}$ (colony forming units)/g of meat.

\subsubsection{Total Zinc Migration}

Zinc ions releasing into fresh poultry meat were determined using an atomic absorption spectrometer (Zeenit 700, Analytikjena, Jena, Germany). Meat samples were mineralized by dry combustion $\left(550{ }^{\circ} \mathrm{C}\right)$, and the metal concentration $(\mathrm{Zn})$ was determined by atomic absorption spectrometry after dissolving the ash residue with nitric acid [46]. Results were expressed as $\mathrm{mg} \mathrm{Zn/kg} \mathrm{fresh} \mathrm{meat.}$

\subsection{Statistical Analysis}

All experiments were conducted using a completely randomized design with three replications. Statistical analysis of data was performed through a one-way analysis of variance (ANOVA) using Software OriginLab (version 8.5) (Northampton, USA), and when ANOVA was significant $(p<0.05)$ differences among mean values were processed by the Tukey test. Significance was defined at $p<0.05$.

\section{Results and Discussion}

The bionanocomposites were successfully produced using the casting method. Thin films produced were homogeneous, yellowish, and transparent (Figure 1).

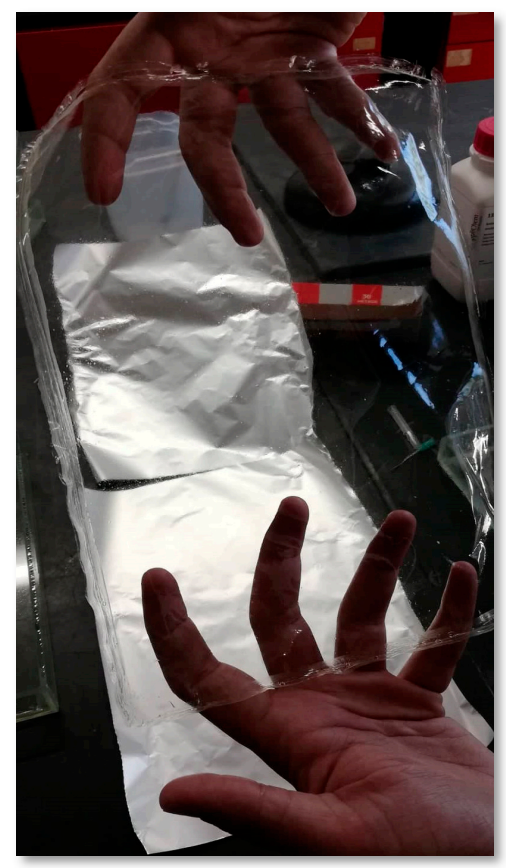

Figure 1. Film obtained by casting method. 


\subsection{In Vitro Antimicrobial Characterization of $\mathrm{ZnO} N P$ and the Bionanocomposites}

Bio-based films' in vitro antimicrobial activity against E. coli and S. aureus are shown in Figure 2. These bacteria strains were chosen to evaluate the bionanocomposites' antimicrobial activity because they are representative of common pathogenic foodborne bacteria, having two distinct types of membranes, i.e., the thicker peptidoglycan layer characteristic of Gram-positive bacteria (S. aureus) and the extra outer impermeable lipid membrane typical of Gram-negative cell wall (E. coli) $[3,19]$.

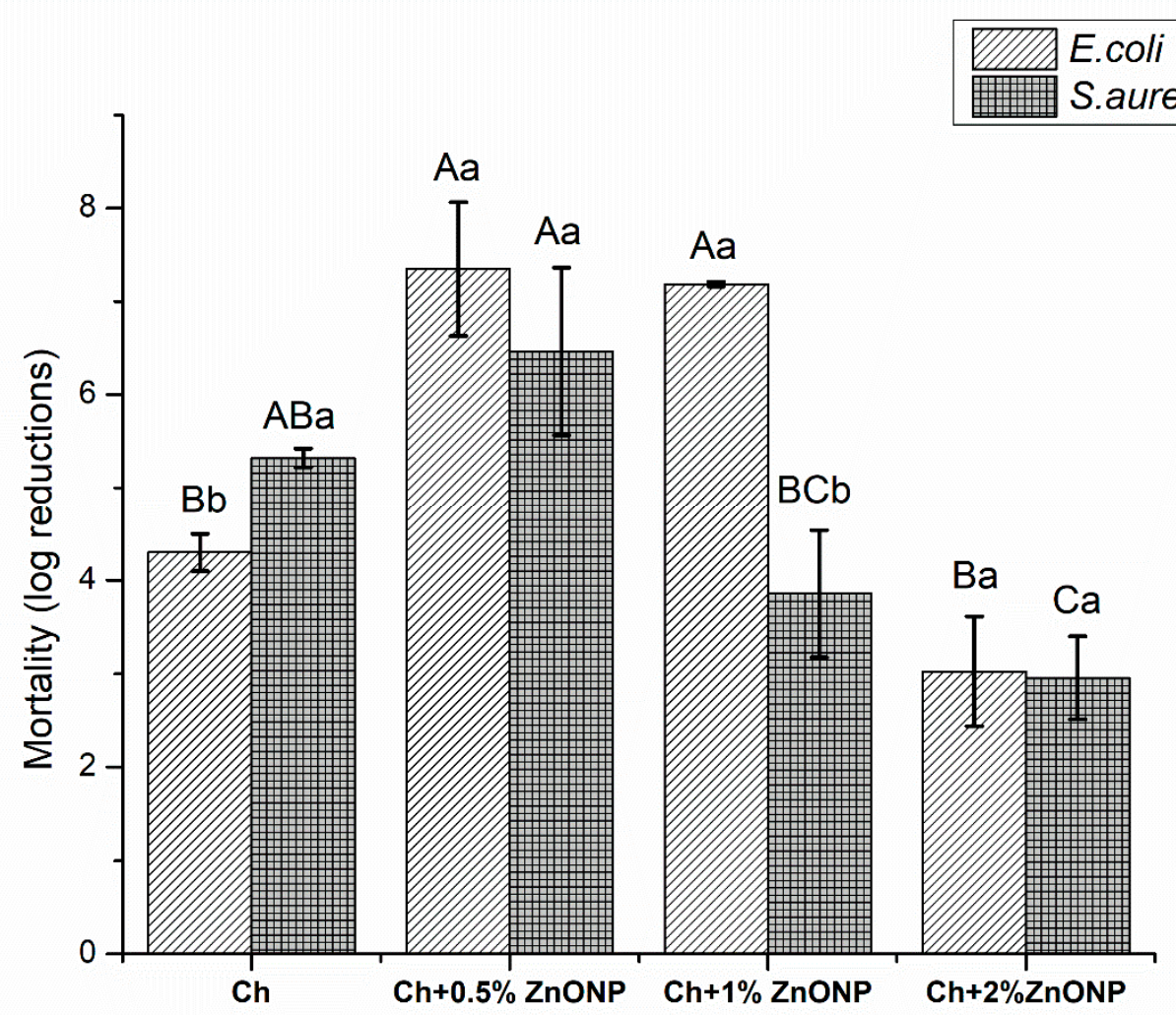

Figure 2. Bionanocomposites in vitro antimicrobial activity. ${ }^{(A-C)}$ : Within each bacterium, values not sharing upper case superscript letters indicate statistically significant differences among formulations $(p<0.05) ;{ }^{(a-b)}$ : Within each formulation/treatment, values not sharing lower case superscript letters indicate statistically significant differences among bacteria $(p<0.05)$. Chitosan $(\mathrm{Ch})$, zinc oxide nanoparticles ( $\mathrm{ZnO} \mathrm{NPs}$ ).

Pristine chitosan film demonstrated a much lower microbial growth for both bacteria tested. The reduction of CFUs was higher $(p<0.05)$ when the control films were in contact to the Gram-positive bacteria (S. aureus) than with the Gram-negative strain (E. coli), with log reductions of 5.32 and 4.3, respectively. These results are in good agreement with previous studies with similar films using the same methodology and microorganisms $[3,8]$. The intrinsic antimicrobial activity of chitosan is often attributed to the positively charged amino groups that interact with negatively charged microbial membranes, leading to changes on the cell membrane's permeability that can result on the leakage of intracellular material, causing the death of the microorganisms [4]. Moreover, the chitosan ability to chelate metals interferes with the flow of essential nutrients to the cell, affecting their metabolism [40]. However, the mode of antimicrobial action of chitosan is not a simple mechanism, but an intricate process that still needs clarification [10]. In general, Gram-positive bacteria are more susceptible than Gram-negative bacteria because, with exceptions, Gram-positive bacteria do not have the outer membrane; thus this outer membrane on Gram-negative cell wall confer more resistance than the thicker peptidoglycan layer from Gram-positive bacteria [11,40]. 
The incorporation of $\mathrm{ZnO} N \mathrm{~N}$ s changed the antibacterial properties of chitosan film $(p<0.05)$ for both bacteria studied (Figure 2). Regarding the first microorganism, E. coli, at the two lower levels of nanoparticles added $(0.5 \%$ and $1 \%)$, the mortality observed on the bacteria was enhanced $(p<0.05)$, which means that an additive effect was present. However, when $2 \%$ of $\mathrm{ZnO}$ NPs was incorporated, the log reduction was lower, if compared to the other bionanocomposites $(p<0.05)$, and did not statistically change to the control film $(p>0.05)$. Similar tendency was observed for the Gram-positive bacteria, S. aureus, films incorporated with $0.5 \%$ of ZnO NPs which presented increased antimicrobial properties. However, the differences were not statistically significant $(p>0.05)$. Higher levels of ZnO NPs decreased the film antibacterial activity in comparison to control films, but only significantly $(p<0.05)$ when $2 \%$ of $\mathrm{ZnO}$ NPs was incorporated. The incorporation of the nanoparticles also changed the antibacterial selectivity of the chitosan films, once the bionanocomposites were more efficient against the Gram-negative bacteria (E. coli) than the Gram-positive one (S. aureus), contrary to what happened with the pristine chitosan film (Figure 2). ZnO NPs were also previously tested by diffusion agar test against the same bacteria, and nanoparticles were also more efficient against $E$. coli than S. aureus: The inhibition halos exhibited against E.coli were on average $7.7 \pm 1.5,12.0 \pm 1.0$, and $13.3 \pm 0.6 \mathrm{~mm}$ for the $\mathrm{ZnO}$ NPs concentration of 100,150 , and $200 \mathrm{mg} / \mathrm{mL}$, respectively. Regarding S. aureus, the results were $0,10.7 \pm 1.2$, and $12.0 \pm 0 \mathrm{~mm}$ for the same concentrations, respectively. $\mathrm{ZnO}$ NPs inhibited E.coli for all the tested ZnO NPs' concentrations and, for S. aureus, ZnO NPs showed only inhibition halos with 150 and $200 \mathrm{mg} / \mathrm{mL}$ concentrations. Lower concentrations of ZnO NPs $(<100 \mathrm{mg} / \mathrm{mL})$ were also tested, but no inhibition halos were observed for both bacteria, probably because the diffusion was not happening properly, once the ZnO NPs were easily deposited in the bottom of the wells cut in the TSA distributed in the Petri dish. Comparing, for the same concentrations, the effect of ZnO NPs for both bacteria, inhibition halos were always smaller when tested on S. aureus than on E. coli. This correlates with the behavior observed for the bionanocomposites, where $\mathrm{ZnO}$ NPs caused a higher growth inhibition of E. coli than S. aureus, suggesting that this change must be attributed to the incorporation of $\mathrm{ZnO}$ NPs.

Antimicrobial activity of ZnO NPs improved with a diminution of the particle size and several mechanisms can explain it, which include the nanoparticle interaction with microorganisms by damaging bacterial cell, by releasing the well-known antimicrobial $\mathrm{Zn}^{2+}$, by forming reactive oxygen species (ROS), especially in the presence of light, or due to the abrasive surface of the nanoparticles [20,32]. Through the electrostatic bonding of $\mathrm{Zn}^{2+}$ to the microorganism cell surface, $\mathrm{ZnO}$ NPs change the permeability of cell membranes, damage cell membranes after its penetration thorough the cell, react with cell components, deplete cytoplasmic content, and interact and inactivate respiratory enzymes [31].

Despite the fact that generally Gram-positive bacteria have higher susceptibility to antimicrobial agents, several authors have also reported higher susceptibility of E. coli to ZnO NPs when compared to $S$. aureus $[21,32,47,48]$. This higher resistance of $S$. aureus to ZnO NPs can be explained by the differences on the intracellular antioxidant content between these two bacteria, i.e., to the carotenoid pigments in the interior of $S$. aureus that promotes a greater oxidant resistance [47]. Moreover, $\mathrm{ZnO}$ NPs have strong affinity with E. coli cells, once their membrane has higher negative charge than the membrane of S. aureus (at biological $\mathrm{pH}$, global charge of bacterial cells is negative while ZnO NPs have a positive charge, these opposite charges generate electrostatic forces, leading to a strong bind between them and, consequently, producing cell membrane damage), and the antimicrobial activity is influenced by the differences in the bacteria susceptibility to ROS [20,21].

The reduction on the antimicrobial activity of the bionanocomposites with an increased content of ZnO NPs can be explained by the agglomeration of NPs, which was not seen in our bionanocomposites through SEM images (results not shown) and/or by blocking of the groups responsible for the antimicrobial activity of the polymer, leading to the reduction of its bioactivity. Similar results were also reported for chitosan film reinforced with montmorillonite and different essential oils [3,8,11]. According to these authors, the good interaction between the active compounds incorporated into the 
polymeric matrices and the functional groups of chitosan may retard the diffusion through the adjacent agar media, diminishing the contact between bacterial cells and active molecules [11,49,50]. Moreover, good interaction between nanoparticles and the polymer may reduce the number of functional groups (amino groups of chitosan) to act in the membrane of microorganisms [11], therefore, diminishing its antimicrobial activity.

\subsection{Application in Fresh Poultry Meat}

Antimicrobial active packaging is the type of material capable to interact with the product or the headspace inside, to reduce, inhibit, or retard the microorganism's growth on food surfaces [51]. The development of nanocomposite with ZnO NPs has been widely done and its antimicrobial activity has been extensively assessed by in vitro studies [20,52]. However, few works have investigated these materials' antimicrobial activity, especially those synthesized with eco-friendly routes, in contact with food [20]. Thus, the results obtained from the contact of these bionanocomposites with poultry meat resulted in a good contribution to understand the role of such novel materials in the preservation of foodstuff.

\subsubsection{Physicochemical Characterization and Thiobarbituric Acid Reactive Substances (TBARS) Index}

In food systems, the oxidative reactions are generally undesired and considered as a deteriorative process responsible for the oxidative degradation of vitamins, pigments, and essential lipids; changes on the food odor and flavor (rancidity); and production of possible toxic compounds, that may pose some risks to the consumer's health [53]. Therefore, avoiding this deteriorative process plays an important role on the maintenance of the food quality and safety and is always sought by the industry in order to extend foodstuff shelf life.

The physicochemical parameters monitored along the cold storage of poultry meat are presented in Table 1. Oxidative profile was assessed through the quantification of TBARS, and indirectly by changes on the meat color. Moreover, $\mathrm{pH}$, titratable acidity, and total volatile basic nitrogen were also parameters used to study the shelf life of the product. 
Table 1. Summary of physicochemical characterization of the meat over the storage time.

\begin{tabular}{|c|c|c|c|c|c|c|}
\hline Parameter & Day & Unwrapped & Ch & $\mathrm{Ch}+0.5 \% \mathrm{ZnO} \mathrm{NPs}$ & $\mathrm{Ch}+1 \% \mathrm{ZnO} \mathrm{NPs}$ & $\mathrm{Ch}+2 \% \mathrm{ZnO} \mathrm{NPs}$ \\
\hline \multirow{5}{*}{$\begin{array}{c}\text { TBARS (mg } \\
\text { Malonaldehyde/kg meat) }\end{array}$} & 0 & $0.039 \pm 0.015^{\mathrm{aC}}$ & $0.039 \pm 0.015^{\mathrm{aC}}$ & $0.039 \pm 0.015^{\mathrm{aB}}$ & $0.039 \pm 0.015^{\mathrm{aB}}$ & $0.039 \pm 0.015^{\mathrm{aB}}$ \\
\hline & 2 & $0.033 \pm 0.013^{\mathrm{aC}}$ & $0.060 \pm 0.022 \mathrm{aC}$ & $0.041 \pm 0.0144^{\mathrm{aB}}$ & $0.037 \pm 0.006^{\mathrm{aB}}$ & $0.033 \pm 0.022^{\mathrm{aB}}$ \\
\hline & 4 & $0.213 \pm 0.144^{\mathrm{aB}}$ & $0.043 \pm 0.005 \mathrm{bC}$ & $0.032 \pm 0.008^{b B}$ & $0.046 \pm 0.008^{b B}$ & $0.037 \pm 0.005^{\mathrm{bB}}$ \\
\hline & 7 & $0.640 \pm 0.012 \mathrm{aA}$ & $0.109 \pm 0.016^{\mathrm{bB}}$ & $0.143 \pm 0.086^{\mathrm{bA}}$ & $0.095 \pm 0.015 \mathrm{bA}$ & $0.121 \pm 0.014 \mathrm{bA}$ \\
\hline & 11 & $0.496 \pm 0.157 \mathrm{aAB}$ & $0.480 \pm 0.283 \mathrm{aA}$ & $0.123 \pm 0.047 \mathrm{bA}$ & $0.104 \pm 0.042^{b A}$ & $0.110 \pm 0.005 \mathrm{bA}$ \\
\hline \multirow{5}{*}{ Hue angle $\left(^{\circ}\right)$} & 0 & $58.9 \pm 0.5^{\mathrm{aC}}$ & $58.9 \pm 0.5^{\mathrm{aC}}$ & $58.9 \pm 0.5^{\mathrm{aAB}}$ & $58.9 \pm 0.5^{\mathrm{aC}}$ & $58.9 \pm 0.5^{\mathrm{aC}}$ \\
\hline & 2 & $61.4 \pm 1.0 \mathrm{aBC}$ & $63.8 \pm 0.1 \mathrm{bcA}$ & $62.5 \pm 0.4 \mathrm{abA}$ & $64.7 \pm 0.1^{\mathrm{cdA}}$ & $65.3 \pm 0.1^{\mathrm{dA}}$ \\
\hline & 4 & $60.8 \pm 1.0 \mathrm{aBC}$ & $60.6 \pm 0.1^{\mathrm{aB}}$ & $61.7 \pm 1.5^{\mathrm{aA}}$ & $61.2 \pm 0.3^{\mathrm{aB}}$ & $60.1 \pm 0.3^{\mathrm{aB}}$ \\
\hline & 7 & $63.6 \pm 2.1 \mathrm{aAB}$ & $57.7 \pm 0.2^{\mathrm{bD}}$ & $57.3 \pm 0.0 \mathrm{bB}$ & $56.7 \pm 0.3^{\mathrm{bD}}$ & $56.7 \pm 0.1 \mathrm{bD}$ \\
\hline & 11 & $65.7 \pm 0.7 \mathrm{aA}$ & $58.4 \pm 0.5^{\mathrm{bcCD}}$ & $60.6 \pm 2.7^{\mathrm{bAB}}$ & $59.3 \pm 0.2 \mathrm{bcC}$ & $56.1 \pm 0.1^{\mathrm{cD}}$ \\
\hline \multirow{5}{*}{$\mathrm{pH}$} & 0 & $6.13 \pm 0.03^{\mathrm{aC}}$ & $6.13 \pm 0.03^{\mathrm{aE}}$ & $6.13 \pm 0.03^{\mathrm{aC}}$ & $6.13 \pm 0.03^{\mathrm{aD}}$ & $6.13 \pm 0.03^{\mathrm{aD}}$ \\
\hline & 2 & $6.13 \pm 0.04^{c C}$ & $6.26 \pm 0.01 \mathrm{aD}$ & $6.25 \pm 0.02 \mathrm{abC}$ & $6.20 \pm 0.01 \mathrm{bD}$ & $6.20 \pm 0.02 b D$ \\
\hline & 4 & $7.07 \pm 0.11^{\mathrm{aB}}$ & $6.68 \pm 0.08^{\mathrm{bcC}}$ & $6.96 \pm 0.23 \mathrm{abB}$ & $6.49 \pm 0.05^{\mathrm{cC}}$ & $6.54 \pm 0.04 \mathrm{cC}$ \\
\hline & 7 & $7.31 \pm 0.23 \mathrm{aB}$ & $6.81 \pm 0.01 \mathrm{bB}$ & $7.21 \pm 0.14 \mathrm{abAB}$ & $6.84 \pm 0.18 \mathrm{bB}$ & $6.84 \pm 0.15 \mathrm{bB}$ \\
\hline & 11 & $7.91 \pm 0.02 \mathrm{aA}$ & $7.51 \pm 0.02^{\mathrm{bA}}$ & $7.39 \pm 0.07 \mathrm{bA}$ & $7.36 \pm 0.11 \mathrm{bA}$ & $7.09 \pm 0.05 \mathrm{cA}$ \\
\hline \multirow{5}{*}{$\begin{array}{l}\text { Titratable acidity (\% oleic } \\
\text { acid equivalent) }\end{array}$} & 0 & $0.73 \pm 0.05^{\mathrm{aAB}}$ & $0.73 \pm 0.05^{\mathrm{aA}}$ & $0.73 \pm 0.05^{\mathrm{aA}}$ & $0.73 \pm 0.05^{\mathrm{aA}}$ & $0.73 \pm 0.05^{\mathrm{aA}}$ \\
\hline & 2 & $0.56 \pm 0.06^{\mathrm{abAB}}$ & $0.65 \pm 0.09 \mathrm{aAB}$ & $0.56 \pm 0.06^{\mathrm{abBC}}$ & $0.45 \pm 0.06^{\mathrm{bA}}$ & $0.53 \pm 0.04^{\mathrm{abA}}$ \\
\hline & 4 & $0.53 \pm 0.15^{\mathrm{aB}}$ & $0.54 \pm 0.10^{\mathrm{aB}}$ & $0.62 \pm 0.04^{\mathrm{aAB}}$ & $0.67 \pm 0.06^{\mathrm{aA}}$ & $0.57 \pm 0.15^{\mathrm{aA}}$ \\
\hline & 7 & $0.66 \pm 0.16^{\mathrm{abAB}}$ & $0.55 \pm 0.00^{\mathrm{bAB}}$ & $0.48 \pm 0.03 \mathrm{bC}$ & $0.81 \pm 0.02^{\mathrm{aA}}$ & $0.64 \pm 0.09 \mathrm{abA}$ \\
\hline & 11 & $0.85 \pm 0.08 \mathrm{aA}$ & $0.55 \pm 0.05^{\mathrm{aB}}$ & $0.56 \pm 0.00 \mathrm{aBC}$ & $0.77 \pm 0.33^{\mathrm{aA}}$ & $0.66 \pm 0.05^{\mathrm{aA}}$ \\
\hline \multirow{5}{*}{$\begin{array}{l}\text { Total volatile basic nitrogen } \\
\qquad(\mathrm{mg} / \mathrm{kg} \text { meat })\end{array}$} & 0 & $47 \pm 18^{\mathrm{aC}}$ & $47 \pm 18^{\mathrm{aBC}}$ & $47 \pm 18^{\mathrm{aB}}$ & $47 \pm 18^{\mathrm{aC}}$ & $47 \pm 18^{\mathrm{aB}}$ \\
\hline & 2 & $11 \pm 2^{b C}$ & $29 \pm 5 \mathrm{aC}$ & $27 \pm 4^{\mathrm{aB}}$ & $57 \pm 35^{\mathrm{aC}}$ & $22 \pm 2^{\mathrm{aB}}$ \\
\hline & 4 & $145 \pm 7$ aB & $80 \pm 4$ bAB & $63 \pm 6^{\mathrm{bB}}$ & $77 \pm 15^{\mathrm{bBC}}$ & $61 \pm 23 \mathrm{bB}$ \\
\hline & 7 & $205 \pm 28$ aA & $78 \pm 14^{\mathrm{bAB}}$ & $117 \pm 25^{\mathrm{bA}}$ & $124 \pm 3^{\mathrm{bAB}}$ & $125 \pm 7^{\mathrm{bA}}$ \\
\hline & 11 & $130 \pm 6^{\mathrm{aB}}$ & $114 \pm 26^{\mathrm{abA}}$ & $70 \pm 0^{\mathrm{bB}}$ & $135 \pm 13^{\mathrm{aA}}$ & $133 \pm 34^{\mathrm{aA}}$ \\
\hline \multirow{5}{*}{ Moisture (\%) } & 0 & $74.5 \pm 0.7^{\mathrm{aC}}$ & $74.5 \pm 0.7^{\mathrm{aA}}$ & $74.5 \pm 0.7 \mathrm{aA}$ & $74.5 \pm 0.7 \mathrm{aA}$ & $74.5 \pm 0.7^{\mathrm{aA}}$ \\
\hline & 2 & $75.1 \pm 0.1^{\mathrm{aBC}}$ & $73.0 \pm 0.0 \mathrm{cB}$ & $73.7 \pm 0.2^{\mathrm{bAB}}$ & $73.6 \pm 0.3^{\mathrm{bA}}$ & $74.0 \pm 0.0^{\mathrm{bB}}$ \\
\hline & 4 & $75.6 \pm 0.1 \mathrm{aAB}$ & $73.2 \pm 0.7^{\mathrm{bcB}}$ & $72.9 \pm 0.2 \mathrm{cAB}$ & $74.0 \pm 0.5^{\mathrm{bA}}$ & $73.4 \pm 0.1^{\mathrm{bcB}}$ \\
\hline & 7 & $75.9 \pm 0.3^{\mathrm{aAB}}$ & $73.1 \pm 0.1 \mathrm{aB}$ & $72.7 \pm 0.5^{\mathrm{aB}}$ & $74.0 \pm 7.0^{\mathrm{aA}}$ & $74.1 \pm 0.4 \mathrm{aAB}$ \\
\hline & 11 & $76.5 \pm 0.2^{\mathrm{aA}}$ & $74.0 \pm 0.1 \mathrm{bcAB}$ & $72.5 \pm 1.1^{\mathrm{cB}}$ & $73.7 \pm 1.1^{\mathrm{bcA}}$ & $75.0 \pm 0.3^{\mathrm{abA}}$ \\
\hline
\end{tabular}

$(\overline{A-E})$ : Within each parameter, values in the same column not sharing upper case superscript letters indicate statistically significant differences among days $(p<0.05)$. (a-c): Within each parameter, values in the same line not sharing lower case superscript letters indicate statistically significant differences among formulations $(p<0.05)$. Thiobarbituric acid reactive substances (TBARS), chitosan (Ch), zinc oxide nanoparticles (ZnO NPs). 
It was observed that the lipid oxidation statistically increased with time for all the samples, $(p<0.05)$ (Table 1), although the unprotected sample and meat protected with pristine chitosan film showed a higher increment than the samples wrapped with chitosan and ZnO NPs. In fact, samples wrapped with bionanocomposites incorporated with ZnO NPs showed less differences on the amount of MDA from day zero to day 11 , demonstrating the material's ability to retard oxidative processes. The unwrapped meat exhibited from day 7 values equal or superior to $0.5 \mathrm{mg} \mathrm{MDA} / \mathrm{kg}$, which is considered as the indicator of rancidity [8]. The meat protected with pristine chitosan, reached the off-flavor trash-hold value only at day 11 . Pristine chitosan film may delay oxidative rancidity in meat due to its good barrier properties against oxygen and light [11], and the chelator characteristic of chitosan, which reacts with metal ions, namely ferrous ions, avoiding lipid peroxidation initiation step, and consequently retarding the chain reactions that lead to deterioration of flavor and taste in foods [54]. Samples protected with the bionanocomposites maintained, until the last day assessed, an MDA value below this limit. Apparently, the incorporation of ZnO NPs into the polymeric matrix enhanced the film's antioxidant ability, probably due to the presence of phenolic compounds from the apple peel used in the synthesis of the nanoparticles [38,55]. In fact, the total phenolic content of $\mathrm{ZnO}$ NPs, determined by the Folin-Ciocalteu method [56] was $7.4 \mathrm{mg}$ gallic acid equivalent/g of $\mathrm{ZnO}$ $\mathrm{NP}$, confirming this hypothesis and the relevance of the ZnO NPs' eco-friendly synthesis based on apple extracts. Antibacterial films based on Gracilaria vermiculophylla extract incorporated with $\mathrm{ZnO}$ NPs also showed a delay on the oxidation process of smoked salmon, reportedly due to the increase on the UV light-blocking property of the composites with the incorporation of nanoparticles [57]. In our study, pristine chitosan film already showed good barrier properties against the UV light, which was slightly increased with the incorporation of ZnO NPs especially when $1 \%$ of nanoparticles was incorporated (data not shown), corroborating the results of Baek and Song (2018) [52], and the lower MDA found for protected meat with the bionanocomposites. Chicken breast meat packaged in low density polyethylene (LDPE) incorporated with $5 \%$ or $10 \%$ of Ag and ZnO NPs was studied in terms of its quality [58], and results indicated also that packaging with nanoparticles delayed lipid oxidation compared to control packaging. The authors suggested that the lower antimicrobial counts associated with the treated nanopackaging influenced lipid oxidation. The relatively high content of unsaturated fatty acid and the low levels of natural antioxidants in poultry meat make this food particularly prone to oxidation. Thus, this novel packaging may be a remarkable alternative on the extension of the shelf life of this type of foodstuff.

Overall, under the refrigerated conditions used, the samples presented an increase on the hue angle, $\mathrm{pH}$, and total volatile basic nitrogen, with decrease on the titratable acidity over time (Table 1). Moisture content increased for unwrapped samples, while it was maintained stable with the protection of films. All changes were more noticeable for the samples nonprotected by the thin films.

Initial hue angle was $58.9^{\circ}$, which represents a reddish tone of color. After the refrigerated storage time, this parameter increased $(p<0.05)$ to a maximum of $65.7^{\circ}$ for unwrapped meat and to around $60^{\circ}$ for the samples protected with the films (Table 1), except for the treatment incorporated with the highest level of ZnO NPs that presented a final hue* of $56.1^{\circ}$ (Table 1), significantly lower than the initial value $(p<0.05)$. Hue angle is a parameter that converts the CIELab coordinators $\mathrm{a}^{*}$ and $\mathrm{b}^{*}$ into color. Smaller angles represent red, while angles close to $90^{\circ}$ represent the yellow [59]. Therefore, an increment on hue* means that the meat sample suffered a discoloration process, once its color is changing toward a more yellowish and greenish tone [8]. In nominal values, results from day 11 in comparison to the initial hue ${ }^{*}$, show that pristine chitosan film and $\mathrm{Ch}+2 \% \mathrm{ZnO}$ NPs reduced the hue*, while films with the intermediate amounts of nanoparticles slightly increased this parameter, however with no statistical significance $(p>0.05)$, except for $\mathrm{Ch}+2 \% \mathrm{ZnO} \mathrm{NPs}(p<0.05)$. This means that the bionanocomposites were capable to maintain the samples' initial reddish color, contrary to the unprotected sample that lost the characteristic red color associated to fresh meat. Since color is the primary attribute influencing consumer choice of chicken meat [58], and consumers are most likely to choose reddish meat over dark and discolored meat $[8,60]$, the bionanocomposites are proven to affect 
positively the quality of this type of food, and might help on the extension of the product shelf life. The amount of ZnO NPs incorporated did not change the outcomes for this parameter $(p>0.05)$. The color retention demonstrated by the application of these films may be related to their antioxidant properties, as discussed before. Moreover, the intrinsic chelating ability of chitosan to scavenge the iron $\left(\mathrm{Fe}^{3+}\right)$ present in the meat may have contributed to retard the oxidative process catalyzed by this metal [61]. Zinc oxide nanoparticles loaded in carboxymethylcellulose (CMC) were prepared and used as coating films of fresh pork meat [62]. The bionanocomposites developed influenced positively the meat color, as protected samples presented increased lightness and redness during storage, which contributed to the visual sensory quality, corroborating our results. According to the authors, a decrease in the $a^{*}$ during cold storage (loss of the redness) may be attributed to the oxidation of oxymyoglobin to metmyoglobin [62].

The $\mathrm{pH}$ is associated to several meat quality attributes, including color, juiciness, tenderness, water retention capacity, and microbial stability. Common $\mathrm{pH}$ values for poultry meat will range from 5.2 to $7[9,63]$. The $\mathrm{pH}$ increased $(p<0.05)$ from the initial value of 6.13 to a maximum of 7.91 for unwrapped meat (Table 1). For the samples protected with the bio-based films, this increment was lower. For instance, the meat protected with $\mathrm{Ch}+2 \% \mathrm{ZnO} N P s$ after 11 days of cold storage presented a value of 7.09, the lowest in comparison to the other treatments. In general, the $\mathrm{pH}$ for the unwrapped sample was statistically higher than the $\mathrm{pH}$ of samples from the other treatments $(p<0.05)$. However, between the protected meat, there was no significant difference $(p>0.05)$, except for the last day of storage $(2 \% \mathrm{ZnO}$ NPs presented the lower $\mathrm{pH}$ ) or at day 2 (films incorporated with nanoparticles showed the smaller $\mathrm{pH}$ value). Complementarily, titratable acidity presented a reduction along time, which was expected since it correlates with the increment of $\mathrm{pH}$ values. The increasing trend on the $\mathrm{pH}$ values was most likely due to the microbiological degradation of proteins that produce alkaline substances, such as amines [62,64]. Similar results were observed for ZnO NPs loaded in CMC that also delayed the increase of $\mathrm{pH}$ levels in pork meat during cold storage [62]. The initial $\mathrm{pH}$ values reported for the fresh pork meat were around 5.70, and after 14 days of storage reached 8.85 for control film and only 6.12 for the meat coated with bionanocomposites. The authors attributed those results to the antimicrobial activity of the films that prevented the production of alkaline substances responsible for the increment of $\mathrm{pH}$ [62].

The total volatile basic nitrogen (TVB-N) content in chicken meat is an important physicochemical index in the assessment of meat freshness and safety evaluation [65]. During storage, protein decomposition by enzymatic degradation and microbial growth generates alkaline nitrogen-containing substances (TVB-N), including ammonia and amines [62]. Therefore, this increase in TVB-N value normally represents the decomposition of the meat. Initial TVB-N content was $47 \mathrm{mg} / \mathrm{kg}$ meat, and, as expected, due to the natural deteriorative process, it was observed an increment of this value during the storage time $(p<0.05)$ for all samples assessed (Table 1). It is important to highlight that this process occurred faster for the unwrapped samples. Whereas at day 4 the TVB-N content was already around $145 \mathrm{mg} / \mathrm{kg}$ meat, samples protected showed results in the range $61-80 \mathrm{mg} / \mathrm{kg}$. At day 7 , the TVB-N content was $205 \mathrm{mg} / \mathrm{kg}$ meat in unwrapped samples and samples protected showed lower results, in the range 78-125 mg/kg meat. Even on the last day evaluated, none of the samples protected with the films reached the amount of TVB-N reported for the unwrapped meat at day 4 or at day 7 . Such results are in line with the data previous reported for $\mathrm{pH}$, acidity, TBARS, and the microbiological growth discussed in Section 3.2.2, representing the spoilage status of the meat samples. Within the different bionanocomposites it was not observed statistical differences $(p>0.05)$ with the incorporation of $\mathrm{ZnO}$ NPs. However, in nominal values at earlier stages of storage (day 4), samples protected with films with ZnO NPs presented slightly smaller TVB-N, and at days 7 and 11 superior than pristine chitosan film (the only exception was for $\mathrm{Ch}+1 \% \mathrm{ZnO} N \mathrm{~N}$ at day 11 , which was the only significantly smaller result observed $(p<0.05)$ ). Suo et al. (2016) [62] also reported an increase on TVB-N content over cold storage of fresh pork meat protected with CMC film incorporated or not with ZnO NP. These authors also concluded that the presence of nanoparticles reduced the values of TVB-N, and the content 
recorded for the samples protected with the active films at day 14 was smaller than for the samples coated with control films without $\mathrm{ZnO}$ NPs at day 6, in good agreement with our results. At day 11 the TVB-N content of the unwrapped meat showed a decay compared to results from day 7 , which can be attributed to the volatilization of ammonia, since the $\mathrm{pH}$ of the meat already reached a high value (7.91).

Finally, the moisture content of the meat packaged with the chitosan films showed a tendency to maintain $(\mathrm{Ch}, \mathrm{Ch}+1 \% \mathrm{ZnO} N P s$, and $\mathrm{Ch}+2 \% \mathrm{ZnO}$ NPs $(p>0.05))$ or decrease $(\mathrm{Ch}+0.5 \% \mathrm{ZnO}$ NPs $(p<0.05)$ ) over time (Table 1). Contrarily, meat unwrapped presented increased water content over storage time $(p<0.05)$. This result may be explained by the barrier created by the films towards the water vapor transport between the meat and the environment, preventing gain or loss of humidity. The slightly smaller moisture obtained after 11 days of storage for the samples protected with the films may be attributed to the hydrophilic character of chitosan films that could have absorbed some water from the samples, as previously observed in other studies with chitosan bionanocomposites $[8,11]$ packaging fresh poultry meat.

\subsubsection{Microbiological Growth}

Poultry meat packaged with the bionanocomposites was evaluated in terms of total aerobic mesophilic and psychrotrophic microorganisms and Enterobacteriaceae over the storage time. The microbiological growth results are shown in Table 2 . The samples presented a natural deteriorative process that can be observed by the increase $(p<0.05)$ of the counting for all bacteria assessed.

Table 2. Summary of the microbiological study of the meat over the storage time.

\begin{tabular}{|c|c|c|c|c|c|c|}
\hline Parameter & Day & Unwrapped & Ch & $\begin{array}{l}\text { Ch }+0.5 \% \\
\text { ZnO NPs }\end{array}$ & $\begin{array}{c}\mathrm{Ch}+1 \% \mathrm{ZnO} \\
\text { NPs }\end{array}$ & $\begin{array}{c}\mathrm{Ch}+2 \% \mathrm{ZnO} \\
\mathrm{NPs}\end{array}$ \\
\hline \multirow{5}{*}{$\begin{array}{c}\text { Total psychrotrophic } \\
\text { aerobic } \\
\text { microorganisms } \\
\text { (Log CFU/g meat) }\end{array}$} & 0 & $3.81 \pm 0.38^{\mathrm{aD}}$ & $3.81 \pm 0.38^{\mathrm{aD}}$ & $3.81 \pm 0.38^{\mathrm{aE}}$ & $3.81 \pm 0.38^{\mathrm{aD}}$ & $3.81 \pm 0.38^{a D}$ \\
\hline & 2 & $6.70 \pm 0.04 \mathrm{aC}$ & $5.48 \pm 0.40^{\mathrm{bC}}$ & $6.13 \pm 0.25 \mathrm{abD}$ & $5.88 \pm 0.01 \mathrm{bC}$ & $5.70 \pm 0.43 \mathrm{bC}$ \\
\hline & 4 & $9.30 \pm 0.21^{\mathrm{aB}}$ & $7.42 \pm 0.01 \mathrm{bcB}$ & $7.39 \pm 0.04 \mathrm{bcC}$ & $7.15 \pm 0.08 \mathrm{cB}$ & $7.58 \pm 0.02 \mathrm{bB}$ \\
\hline & 7 & $9.87 \pm 0.03 \mathrm{aA}$ & $8.87 \pm 0.08^{b A}$ & $8.75 \pm 0.09 \mathrm{bB}$ & $9.00 \pm 0.24 \mathrm{bA}$ & $9.00 \pm 0.38^{b A}$ \\
\hline & 11 & $9.79 \pm 0.13^{\mathrm{aAB}}$ & $7.96 \pm 0.01 \mathrm{bB}$ & $9.36 \pm 0.03^{\mathrm{aA}}$ & $8.90 \pm 0.94 \mathrm{abA}$ & $9.52 \pm 0.52^{\mathrm{aA}}$ \\
\hline \multirow{5}{*}{$\begin{array}{c}\text { Total mesophilic } \\
\text { aerobic } \\
\text { microorganisms } \\
\text { (Log CFU/g meat) }\end{array}$} & 0 & $3.46 \pm 0.33^{\mathrm{aC}}$ & $3.46 \pm 0.33^{\mathrm{aD}}$ & $3.46 \pm 0.33^{\mathrm{aE}}$ & $3.46 \pm 0.33^{\mathrm{aE}}$ & $3.46 \pm 0.33^{\mathrm{aD}}$ \\
\hline & 2 & $6.07 \pm 0.29^{\mathrm{aB}}$ & $5.35 \pm 0.32^{\mathrm{aC}}$ & $6.11 \pm 0.37^{\mathrm{aD}}$ & $5.73 \pm 0.02^{\mathrm{aD}}$ & $5.44 \pm 0.33^{\mathrm{aC}}$ \\
\hline & 4 & $9.25 \pm 0.25^{\mathrm{aA}}$ & $7.34 \pm 0.06^{b B}$ & $7.41 \pm 0.05^{b C}$ & $7.02 \pm 0.23 \mathrm{bC}$ & $7.42 \pm 0.07^{b B}$ \\
\hline & 7 & $9.73 \pm 0.04^{\mathrm{aA}}$ & $8.69 \pm 0.17^{b A}$ & $8.62 \pm 0.05^{b B}$ & $9.00 \pm 0.26^{b B}$ & $8.90 \pm 0.46^{\mathrm{bA}}$ \\
\hline & 11 & $9.79 \pm 0.16^{\mathrm{aA}}$ & $8.58 \pm 0.33^{b A}$ & $9.25 \pm 0.09 \mathrm{abA}$ & $9.66 \pm 0.02^{\mathrm{aA}}$ & $9.48 \pm 0.57^{\mathrm{aA}}$ \\
\hline \multirow{5}{*}{$\begin{array}{l}\text { Enterobacteriaceae } \\
\text { (Log CFU/g meat) }\end{array}$} & 0 & $3.68 \pm 0.10^{\mathrm{aE}}$ & $3.68 \pm 0.10^{a B}$ & $3.68 \pm 0.10 \mathrm{aBC}$ & $3.68 \pm 0.10^{a B}$ & $3.68 \pm 0.10^{a B}$ \\
\hline & 2 & $4.32 \pm 0.24 \mathrm{aD}$ & $2.86 \pm 0.06^{\mathrm{bC}}$ & $3.42 \pm 0.53 \mathrm{bBC}$ & $3.32 \pm 0.15^{\mathrm{bB}}$ & $3.37 \pm 0.15 b B$ \\
\hline & 4 & $4.75 \pm 0.09 \mathrm{aC}$ & $2.93 \pm 0.37 \mathrm{bC}$ & $2.89 \pm 0.63 \mathrm{bC}$ & $1.46 \pm 0.50^{\mathrm{cC}}$ & $2.38 \pm 0.42 \mathrm{bcB}$ \\
\hline & 7 & $5.82 \pm 0.13^{\mathrm{aB}}$ & $3.48 \pm 0.01 \mathrm{bB}$ & $4.08 \pm 0.16^{\mathrm{bB}}$ & $3.85 \pm 0.53 \mathrm{bB}$ & $3.70 \pm 1.13 \mathrm{bB}$ \\
\hline & 11 & $7.22 \pm 0.01^{\mathrm{aA}}$ & $5.40 \pm 0.18 \mathrm{cA}$ & $5.56 \pm 0.02^{\mathrm{bcA}}$ & $5.37 \pm 0.06^{\mathrm{cA}}$ & $5.67 \pm 0.04 \mathrm{bA}$ \\
\hline
\end{tabular}

(A-E): Within each parameter, values in the same column not sharing upper case superscript letters indicate statistically significant differences among days $(p<0.05)$. ${ }^{(a-c)}$ : Within each parameter, values in the same line not sharing lower case superscript letters indicate statistically significant differences among formulations $(p<0.05)$. Chitosan (Ch), zinc oxide nanoparticles (ZnO NPs).

As it was expected, poultry meat without wrapping presented higher contamination and faster growth. Total mesophilic and psychrotrophic aerobic microorganisms presented a similar behavior, and overall, total count of psychrotrophic microorganisms were slightly higher than total mesophilic. This is because the samples were kept refrigerated, and, therefore, the existing contaminants were more adapted and capable to survive in these conditions. The evaluation of psychrotrophic microorganisms is relevant in poultry meat samples. Once under refrigeration storage, most of psychrophilic strains are spoilage microorganisms and some pathogenic (e.g., L. monocytogenes), thus, responsible for changing the quality and safety of the product [66].

The initial contamination of psychrotrophic aerobic microorganisms was $3.81 \log \mathrm{CFU} / \mathrm{g}$ meat and after 11 days of storage it reached the maximum of $9.79 \log \mathrm{CFU} / \mathrm{g}$ meat for the samples without 
protection, while the minimum was observed for the meat protected with the chitosan film (control film, $7.96 \log$ CFU/g meat), a reduction of almost $2 \log$ (Table 2). Within the films incorporated with ZnO NPs, the differences on total psychrotrophic aerobic microorganisms (TPAM) did not have statistical significance $(p>0.05)$, and the contamination was higher than the one obtained with the pristine chitosan sample. Again, this may reflect the good interaction between nanoparticles and the polymer that can reduce the number of functional groups (amino groups of chitosan) to act in the membrane of microorganisms [11], therefore, diminishing its antimicrobial activity, and explains why, with $2 \%$ $\mathrm{ZnO} N P s$, the film presented less antimicrobial activity. However, the trend observed was that meat wrapped with films incorporated with ZnO NPs presented lower contamination than the unwrapped meat. Earlier, at storage days 2, 4, and 7, the protection effect of bionanocomposites compared to the pristine chitosan didn't show significant differences or even perform better. For instance, the samples protected with films added with $1 \%$ of $\mathrm{ZnO}$ NPs showed the smaller contamination of TPAM at day 4 , with a reduction of $2.15 \mathrm{log}$ in the enumeration of TPAM when compared to unwrapped samples. The same pattern was observed with total mesophilic aerobic microorganisms (TMAM). Nevertheless, in terms of organoleptic/sensory acceptance, fresh poultry meat is considered rejected when the total aerobic microorganisms count exceed $7 \log \mathrm{CFU} / \mathrm{g}$ [67]. At day 2 of storage, unwrapped meat presented an enumeration of TPAM near this limit $(6.70 \log \mathrm{CFU} / \mathrm{g})$, while the coated samples showed a lower enumeration (in the range 5.48-6.13 $\log$ CFU/g,). At day 4, unprotected samples' TPAM and TMAM was by more than $2 \log$ higher than the limit, while the samples protected with the biopolymers only passed the limit by $0.15-0.58 \log$ in the case of TPAM and by $0.02-0.45 \log$ in the case of TMAM. Thus, the results highlighted these coatings as a tool to enlarge the organoleptic/sensory acceptance period of poultry meat products.

Foodstuffs should not contain microorganisms or their toxins or metabolites in quantities that present an unacceptable risk for human health, and, according to the Regulation of the European Commission (EC) No. 2073/2005 [68], the maximum limit for aerobic colony counting in noncooked minced meat is $6.70 \log \mathrm{CFU} / \mathrm{g}$ meat. Results superior to this limit indicate that hygienic production and/or selection of raw materials must be improved. The initial contamination for both mesophilic and psychrotrophic aerobic microorganisms were below the maximum established in the European regulation for minced meat, $3.46 \log \mathrm{CFU} / \mathrm{g}$ meat and $3.81 \log \mathrm{CFU} / \mathrm{g}$ meat, respectively, and those values are in good agreement with previous results (4.0 log CFU/g [31], $4.3 \log$ CFU/g [67], $4.85 \log$ CFU/g [54]) for fresh chicken breast meat. This limit was passed at day 4 of storage for all the samples wrapped with biopolymers (by a maximum of $0.89 \log$ for TPAM and $0.73 \log$ for TMAM), and for the unwrapped samples by $2.59 \mathrm{log}$ in terms of TMAM, while the unwrapped samples showed a contamination superior to the limit immediately at day 2 of storage for the psychrotrophic microorganisms. This demonstrates that this technology is capable to protect this type of food, extending its shelf life at least 1-2 days more (Table 2). The biopolymers helped to slow down the microbial propagation, compared to unwrapped meat, but did not inhibit the microbial spoilage. Growth of microbes in the vicinity of the composites was most probably inhibited, as it was seen in the antimicrobial tests, but the rest of them continued to grow. The same behavior of films over time has also been reported in other studies. Total aerobic bacterial counts in orange juice with LDPE film containing $1 \%$ ZnO NPs increased after 7 days, similar to the control [69]. Strawberries packed in LDPE with 3\% ZnO NPs decreased the aerobic counting until day 4 and then increased again on day 8 [70].

The European Food Safety Authority (EFSA) recommends in both the manufacturing environment and the finished product the monitoring and testing of Enterobacteriaceae. However, besides pathogenic species, the family Enterobacteriaceae also includes environmental species, which often appear in the food manufacturing environment without posing any health hazard [68]. Thus, the family Enterobacteriaceae can be used for routine monitoring. The initial counting for this family of bacteria was $3.68 \log \mathrm{CFU} / \mathrm{g}$ of meat, and this contamination statistically increased $(p<0.05)$ over storage time, reaching, at the last day, a maximum of $7.22 \log \mathrm{CFU} / \mathrm{g}$ meat for the unwrapped samples (Table 2). Concerning the wrapped samples, the contamination was always significantly lower than the unwrapped samples. 
However, between the bionanocomposites there was no significance differences $(p>0.05)$, but in nominal values, film incorporated with $1 \%$ of $\mathrm{ZnO}$ NPs presented the smaller counting at days 4 and 11. Enterobacteriaceae, a psychrotrophic facultative anaerobic bacterial group, is a large family of Gram-negative bacteria and, as discussed before for the in vitro antimicrobial activity, Gram-negative bacteria were more susceptible to the antimicrobial effect of $\mathrm{ZnO} N P s$, which correlates with the results found in this in situ study.

Similar enumeration for Enterobacteriaceae was reported for chicken breast meat [54], where the initial contamination found was around $3 \log \mathrm{CFU} / \mathrm{g}$ meat, and reached a maximum of $6 \log \mathrm{CFU} / \mathrm{g}$ meat after 12 days under modified atmosphere packaging and refrigeration conditions. The authors also tested the influence of chitosan dipping combined or not with oregano essential oil and concluded that both pristine chitosan coating and with the essential oil reduced approximately 3-4 log CFU/g meat on the Enterobacteriaceae counts, which is in good agreement with our results.

Other studies have investigated the effectiveness of composites with ZnO NPs on the preservation of food and concluded that nanoparticles are capable to protect the food packaged, extending its shelf life: CMC film incorporated with ZnO NPs was used to protect pork meat under cold storage, and it was concluded that nanoparticles were able to extend the shelf life of the product by reducing the total microbial count of the samples protected by them [62]. Nanocomposite films with CMC, okra mucilage, and $\mathrm{ZnO}$ NPs were effective in the preservation of chicken breast meat during 12 days of cold storage, and it was observed that samples with active films did not reach the maximum limit established on the Iranian regulation for total viable counting, demonstrating the remarkable potential of this technology to preserve food products [33]. Novel active packaging based on CMC/chitosan-ZnO NPs was produced and its performance was evaluated on the shelf life extension of sliced bread [71], through the application of films with $0 \%, 0.5 \%, 1 \%$, or $2 \%$ of nanoparticles as edible coating or thin films in the protection against fungal growth of fresh bread without preservatives. The samples without protection presented fungi growth after 3 days, while when ZnO NPs was incorporated, the presence of microorganisms occurred only at day 11,15 , or 22 for films with $0.5 \%, 1 \%$, and $2 \% \mathrm{ZnO}$ NPs, respectively. Thus, ZnO NPs proved to enhance the antimicrobial activity of films and extend the shelf life of the product packaged.

In fact, the presence and growth of spoilage and pathogenic microorganisms, together with oxidative reactions, are the main factors determining the quality of fresh meat, since these products are very likely to be contaminated with microorganisms if not properly preserved and handled. So it is desirable to use preservatives with antimicrobial properties and active packaging, as thin film or coating, to improve food quality and safety $[8,11,72]$.

\subsubsection{Total Zinc Migration}

When developing novel materials intended to be used in direct contact with foodstuff, the study of total migration and toxicologic effects are mandatory [16]. According to European Food Safety Authority (EFSA) panel on food contact materials, enzymes, flavorings, and processing aids (CEF Panel), zinc oxide does not migrate in nanoform, and therefore, the safety evaluation is focused on the migration of soluble ionic zinc. Although zinc is an essential element for human's physiological activity, in 2003 the CEF Panel established for zinc a no-observed adverse effect level of $50 \mathrm{mg} /$ person per day and an upper limit of $25 \mathrm{mg} /$ person per day was recommended [23]. Taking into consideration these recommendations, the total zinc content of the fresh poultry meat at initial time and after 11 days of cold storage for all the bionanocomposites used was analyzed and the results are presented in Table 3.

An initial content of zinc ions was of $13.2 \mathrm{mg} / \mathrm{kg}$ meat. This result is in good agreement with the $8 \mathrm{mg} / \mathrm{kg}$ meat established by the official Portuguese database (PortFIR) for chicken breast [73]. After the storage time, no differences were observed, either for unwrapped meat or for the samples protected with pristine chitosan film $(p>0.05)$ (Table 3). Contrarily, poultry meat protected with bionanocomposites showed increased levels of zinc $(p<0.05)$, probably due to the zinc present in the packaging (ZnO NPs) that diffused toward the food packaged (Table 3). Moreover, it was observed a 
concentration effect, once the samples were wrapped with $\mathrm{Ch}+2 \% \mathrm{ZnO}$ NPs, reported the highest amount of zinc.

Table 3. Total zinc migration.

\begin{tabular}{ccc}
\hline Sample & $\begin{array}{c}\text { Zinc Content } \\
\text { (mg Zn/kg Fresh Meat) }\end{array}$ & $\begin{array}{c}\text { \% Diffused } \\
\text { (mg Zn Diffused/Maximum Incorporated) }\end{array}$ \\
\hline Initial zinc content - day 0 & $13.2 \pm 3.4^{\mathrm{C}}$ & - \\
Unwrapped - day 11 & $13.3 \pm 0.9^{\mathrm{C}}$ & - \\
Chitosan - day 11 & $18.1 \pm 0.2^{\mathrm{C}}$ & - \\
Ch+0.5\% ZnO NP - day 11 & $44.9 \pm 1.1^{\mathrm{B}}$ & $92.9 \%$ \\
Ch+1.0\% ZnO NP - day 11 & $40.9 \pm 0.5^{\mathrm{B}}$ & $39.4 \%$ \\
Ch+2.0\% ZnO NP - day 11 & $61.6 \pm 7.5^{\mathrm{A}}$ & $37.7 \%$ \\
\hline
\end{tabular}

${ }^{(A-C)}$ : Values not sharing upper case superscript letters indicate statistically significant differences among formulations $(p<0.05)$. Chitosan $(\mathrm{Ch})$, zinc oxide nanoparticles ( $\mathrm{ZnO} \mathrm{NP})$.

In average for the packaging with $0.5 \% \mathrm{ZnO} N P s$ or $1 \% \mathrm{ZnO}$ NPs the increment of zinc was around $30 \mathrm{mg} / \mathrm{kg}$ meat, while for the $2 \% \mathrm{ZnO}$ NPs was approximately $50 \mathrm{mg} / \mathrm{kg}$ meat. If, on average, a medium portion has $100 \mathrm{~g}$, results from Table 3 show that the meat wrapped with these bionanocomposites, having 4-6 mg Zn per portion, represents $16 \%-24 \%$ of the upper limit intake of zinc recommended per person per day. However, further studies still need to be carried out in order to assess its safety toward the consumers' exposure.

The percentage of zinc diffused in relation to the amount incorporated decreased with the increment of the amount of zinc added (Table 3), i.e., film with $0.5 \% \mathrm{ZnO} N P s$ presented around $93 \%$ of zinc diffused, followed by $39.4 \%$ and $37.7 \%$ for $1 \%$ and $2 \%$ ZnO NPs, respectively. The changes in the internal polymer bonding organization due to the incorporation of the nanoparticles, and due to the organization of NPs among themselves, might be responsible for these results. In fact, zinc oxide nanoparticles incorporated at $0.5 \%$ resulted in the highest water vapor permeability and smallest tensile strength (data not shown), contributing to a facilitated diffusion process of ZnO NPs. This result also corroborates with the in vitro antimicrobial activity of the bionanocomposites, where the films incorporated with the smallest amount of ZnO NPs presented the highest growth inhibition of the bacteria tested, probably due to the superior diffusion of the active compounds towards the media, as observed here.

\section{Final Considerations and Conclusions}

Bionanocomposites were successfully produced as thin, transparent, yellowish films. The material presented good antimicrobial properties against two bacterial strains, and the incorporation of $\mathrm{ZnO}$ NP enhanced such characteristic, especially against Gram-negative foodborne bacteria. Overall, the perfect food package is still a goal. Despite the improved meat conservation with the proposed bionanocomposites, these have distinct properties that favor their application towards different uses (e.g., application on other food matrices, also as carrier for active compounds, in agriculture, etc.). While $\mathrm{Ch}$ alone has a distinctive positive role against TPAM and TMAM, other properties are favored by adding ZnO NPs, especially on the antioxidant activity represented by the reduction on TBARS values and the discoloration process. From adding $0.5 \%, 1 \%$, or $2 \%$, different properties of the bionanocomposite will be enhanced, with those highlighted in the bionanocomposite with $0.5 \%$ (predominantly antibacterial) being the most decisive to an improved food packaging material. Fresh poultry meat protected with the films presented an extension on its shelf-life time, proving that this technology has a promising potential to be applied by the food industry. Regarding the best formulation to be chosen for this type of food, analyzing Figure 3, it is reasonable to conclude that between the three levels of $\mathrm{ZnO}$ NPs tested, the preservation achieved was quite similar. However, bionanocomposites with $1 \%$ of NPs presented closer to the acceptance area (total psychrotrophic count lower than $7 \log$ CFU/g meat and TBARS lower than $0.5 \mathrm{mg}$ MDA $/ \mathrm{kg}$ meat) and, therefore, can be 
picked as the best formulation for this type of foodstuff. The increase on the amount of zinc in the samples protected by the $\mathrm{ZnO}$ films demonstrated that a release of such compound occurred, and despite zinc oxide being listed as GRAS, further studies still need to be carried out in order to assess its safety toward the consumers' exposure or to the environment after disposal. Indeed, current data is still not enough, e.g., to understand how those particles migrate, if they really kept or lost their nanoform, and also their bioavailability. Moreover, the detection or identification of nanoparticles in the food matrices or environmental containers poses challenges [74]. In addition, a better clarification is needed to understand if the toxicity is due to the high $\mathrm{Zn}$ dose or to the $\mathrm{ZnO}$ nanoparticles themselves [75].

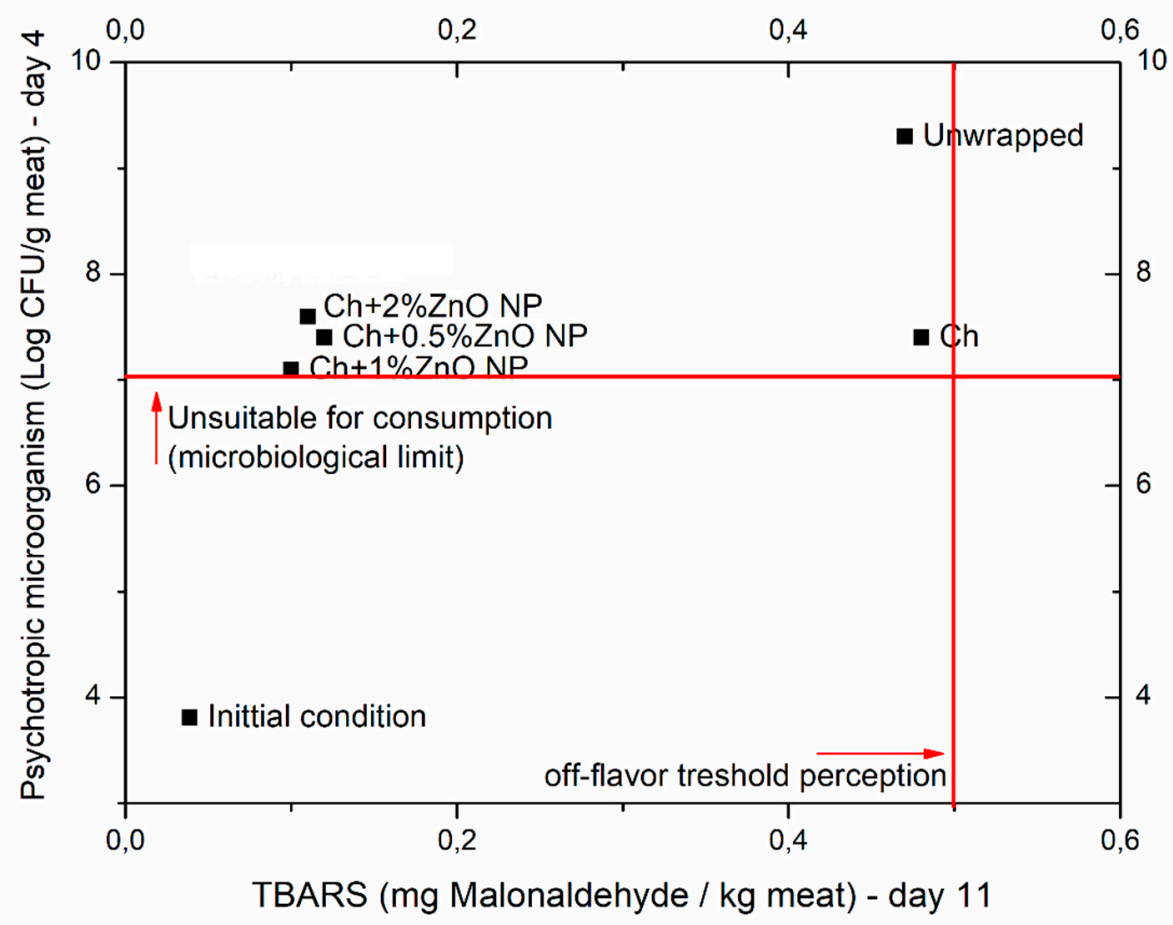

Figure 3. Plot of lipid oxidation and microbiology study results of poultry meat packaged in chitosan (Ch)-based film incorporated with different levels of zinc oxide nanoparticles ( $\mathrm{ZnO} N \mathrm{~N}$ ) over the shelf-life time.

Supplementary Materials: The following are available online at http://www.mdpi.com/2079-6412/10/2/110/s1, Figure S1: Physicochemical characterization of the ZnO NPs; a) Scanning electron microscopy (SEM) image, and b) X-ray diffractogram.

Author Contributions: Conceptualization, V.G.L.S., M.M.A., C.F.S., I.M.C. and A.L.F.; methodology, V.G.L.S., M.M.A., C.F.S., I.M.C., C.R., J.R.A.P., C.P., S.V. and A.L.F.; software, V.G.L.S.; formal analysis, V.G.L.S., C.R, S.V., C.P. and J.R.A.P.; resources, V.G.L.S., M.M.A., I.M.C. and A.L.F.; data curation, V.G.L.S. and A.L.F.; writing-original draft preparation, V.G.L.S., M.M.A., C.F.S., I.M.C. C.R., J.R.A.P. and A.L.F.; writing-review and editing, V.G.L.S., M.M.A., C.F.S., I.M.C. and A.L.F.; supervision, I.M.C. and A.L.F.; project administration, A.L.F.; funding acquisition, M.M.A., C.F.S., I.M.C. and A.L.F. All authors have read and agreed to the published version of the manuscript.

Funding: This work was supported by Mechanical Engineering and Resource Sustainability Center (MEtRICs) unit, which is financed by national funds from Fundação para a Ciência e a Tecnologia (FCT)/Ministério da Ciência, Tecnologia e Ensino Superior (MCTES) (UID/EMS/04077/2019). This work was also supported by the Associate Laboratory for Green Chemistry (LAQV), which is financed by national funds from FCT/MCTES (UID/QUI/50006/2019), and CQE (Centro de Química Estrutural) project UID/QUI/00100/2019. M.M.A. gives thanks to the Instituto Superior Técnico for Scientific Employment contract (Contrato No: IST-ID/154/2018) under Decree-Law No. 57/2016 and 57/2017.

Conflicts of Interest: The authors declare no conflict of interest. The founding sponsors had no role in the design of the study; in the collection, analyses, or interpretation of data; in the writing of the manuscript, and in the decision to publish the results. 


\section{References}

1. Corrado, S.; Sala, S. Food waste accounting along global and European food supply chains: State of the art and outlook. Waste Manag. 2018, 79, 120-131. [CrossRef] [PubMed]

2. Spada, A.; Conte, A.; Del Nobile, M.A. The influence of shelf life on food waste: A model-based approach by empirical market evidence. J. Clean. Prod. 2018, 172, 3410-3414. [CrossRef]

3. Souza, V.G.L.; Rodrigues, C.; Ferreira, L.; Pires, J.R.A.; Duarte, M.P.; Coelhoso, I.; Fernando, A.L. In vitro bioactivity of novel chitosan bionanocomposites incorporated with different essential oils. Ind. Crops Prod. 2019, 140, 111563. [CrossRef]

4. Dutta, P.K.; Tripathi, S.; Mehrotra, G.K.; Dutta, J. Perspectives for chitosan based antimicrobial films in food applications. Food Chem. 2009, 114, 1173-1182. [CrossRef]

5. Sánchez-González, L.; Cháfer, M.; Hernández, M.; Chiralt, A.; González-Martínez, C. Antimicrobial activity of polysaccharide films containing essential oils. Food Control 2011, 22, 1302-1310. [CrossRef]

6. Souza, V.G.L.; Rodrigues, P.F.; Duarte, M.P.; Fernando, A.L. Antioxidant Migration Studies in Chitosan Films Incorporated with Plant Extracts. J. Renew. Mater. 2018, 6, 548-558. [CrossRef]

7. Ferreira, A.R.V.; Alves, V.D.; Coelhoso, I.M. Polysaccharide-based membranes in food packaging applications. Membranes 2016, 6, 22. [CrossRef]

8. Souza, V.G.L.; Pires, J.R.; Vieira, É.T.; Coelhoso, I.M.; Duarte, M.P.; Fernando, A.L. Shelf life assessment of fresh poultry meat packaged in novel bionanocomposite of chitosan/montmorillonite incorporated with ginger essential oil. Coatings 2018, 8, 177. [CrossRef]

9. Pires, J.R.A.; de Souza, V.G.L.; Fernando, A.L. Chitosan/montmorillonite bionanocomposites incorporated with rosemary and ginger essential oil as packaging for fresh poultry meat. Food Packag. Shelf Life 2018, 17, 142-149. [CrossRef]

10. Kong, M.; Chen, X.G.; Xing, K.; Park, H.J. Antimicrobial properties of chitosan and mode of action: A state of the art review. Int. J. Food Microbiol. 2010, 144, 51-63. [CrossRef]

11. Souza, V.G.L.; Pires, J.R.A.; Vieira, É.T.; Coelhoso, I.M.; Duarte, M.P.; Fernando, A.L. Activity of chitosan-montmorillonite bionanocomposites incorporated with rosemary essential oil: From in vitro assays to application in fresh poultry meat. Food Hydrocoll. 2019, 89, 241-252. [CrossRef]

12. Souza, V.G.L.; Pires, J.R.A.; Rodrigues, C.; Rodrigues, P.F.; Lopes, A.; Silva, R.J.; Caldeira, J.; Duarte, M.P.; Fernandes, F.B.; Coelhoso, I.M.; et al. Physical and morphological characterization of chitosan/montmorillonite films incorporated with ginger essential oil. Coatings 2019, 9, 700. [CrossRef]

13. Souza, V.G.L.; Pires, J.R.A.; Rodrigues, P.F.; Lopes, A.A.S.; Fernandes, F.M.B.; Duarte, M.P.; Coelhoso, I.M.; Fernando, A.L. Bionanocomposites of chitosan/montmorillonite incorporated with Rosmarinus officinalis essential oil: Development and physical characterization. Food Packag. Shelf Life 2018, 16, 148-156. [CrossRef]

14. Mao, H.; Wei, C.; Gong, Y.; Wang, S.; Ding, W. Mechanical and water-resistant properties of eco-friendly chitosan membrane reinforced with cellulose nanocrystals. Polymers 2019, 11, 166. [CrossRef] [PubMed]

15. Pires, J.R.A.; Souza, V.G.L.; Fernando, A.L. Valorization of energy crops as a source for nanocellulose production - Current knowledge and future prospects. Ind. Crops Prod. 2019, 140, 111642. [CrossRef]

16. Souza, V.G.L.; Ribeiro-Santos, R.; Rodrigues, P.F.; Otoni, C.G.; Duarte, M.P.; Coelhoso, I.M.; Fernando, A.L. Nanomaterial migration from composites into food matrices. In Composite Materials For Food Packaging; Cirillo, G., Kozlowski, M.A., Spizzirri, U.G., Eds.; Scrivener Publishing LLC: Beverly, MA, USA, 2018; p. 465. ISBN 9781119160205.

17. Youssef, A.M.; Abou-Yousef, H.; El-Sayed, S.M.; Kamel, S. Mechanical and antibacterial properties of novel high performance chitosan/nanocomposite films. Int. J. Biol. Macromol. 2015, 76, 25-32. [CrossRef]

18. Tian, F.; Chen, W.; Wu, C.E.; Kou, X.; Fan, G.; Li, T.; Wu, Z. Preservation of Ginkgo biloba seeds by coating with chitosan/nano-TiO 2 and chitosan/nano-SiO 2 films. Int. J. Biol. Macromol. 2019, 126, 917-925. [CrossRef]

19. Jay, J.M.; Loessner, M.J.; Golde, D.A. Modern Food Microbiology, 7th ed.; Springer: New York, NY, USA, 2005; ISBN 0-387-23180-3.

20. Espitia, P.J.P.; Soares, N.; dos Reis Coimbra, J.S.; de Andrade, N.J.; Cruz, R.S.; Medeiros, E.A. Zinc oxide nanoparticles: synthesis, antimicrobial activity and food packaging Applications. Food Bioprocess Technol. 2012, 5, 1447-1464. [CrossRef]

21. Applerot, G.; Perkas, N.; Amirian, G.; Girshevitz, O.; Gedanken, A. Coating of glass with ZnO via ultrasonic irradiation and a study of its antibacterial properties. Appl. Surf. Sci. 2009, 256, 3-8. [CrossRef] 
22. Chaudhry, Q.; Scotter, M.; Blackburn, J.; Ross, B.; Boxall, A.; Castle, L.; Aitken, R.; Watkins, R. Applications and implications of nanotechnologies for the food sector. Food Addit. Contam. Part A. Chem. Anal. Control. Expo. Risk Assess. 2008, 25, 241-258. [CrossRef]

23. Bolognesi, C.; Castle, L.; Cravedi, J.; Engel, K.; Franz, R.; Fowler, P.; Grob, K.; Gürtler, R.; Husøy, T.; Sirpa, K. European Food Safety Authority (EFSA) Safety assessment of the substance zinc oxide, nanoparticles, for use in food contact materials. EFSA J. 2016, 14, 4408. [CrossRef]

24. Kołodziejczak-Radzimska, A.; Jesionowski, T. Zinc Oxide-From Synthesis to Application: A Review. Materials 2014, 7, 2833-2881. [CrossRef] [PubMed]

25. Agarwal, H.; Venkat Kumar, S.; Rajeshkumar, S. A review on green synthesis of zinc oxide nanoparticles An eco-friendly approach. Resour. Technol. 2017, 3, 406-413. [CrossRef]

26. Yuvakkumar, R.; Suresh, J.; Nathanael, A.J.; Sundrarajan, M.; Hong, S.I. Novel green synthetic strategy to prepare $\mathrm{ZnO}$ nanocrystals using rambutan (Nephelium lappaceum L.) peel extract and its antibacterial applications. Mater. Sci. Eng. C 2014, 41, 17-27. [CrossRef] [PubMed]

27. Nava, O.J.; Soto-Robles, C.A.; Gómez-Gutiérrez, C.M.; Vilchis-Nestor, A.R.; Castro-Beltrán, A.; Olivas, A.; Luque, P.A. Fruit peel extract mediated green synthesis of zinc oxide nanoparticles. J. Mol. Struct. 2017, 1147, 1-6. [CrossRef]

28. Alves, M.M.; Andrade, S.M.; Grenho, L.; Fernandes, M.H.; Santos, C.; Montemor, M.F. Influence of apple phytochemicals in $\mathrm{ZnO}$ nanoparticles formation, photoluminescence and biocompatibility for biomedical applications. Mater. Sci. Eng. C 2019, 101, 76-87. [CrossRef]

29. Akbar, A.; Anal, A.K. Zinc oxide nanoparticles loaded active packaging, a challenge study against Salmonella typhimurium and Staphylococcus aureus in ready-to-eat poultry meat. Food Control 2014, 38, 88-95. [CrossRef]

30. Al-Naamani, L.; Dobretsov, S.; Dutta, J. Chitosan-zinc oxide nanoparticle composite coating for active food packaging applications. Innov. Food Sci. Emerg. Technol. 2016, 38, 231-237. [CrossRef]

31. Noshirvani, N.; Ghanbarzadeh, B.; Mokarram, R.R.; Hashemi, M.; Coma, V. Preparation and characterization of active emulsified films based on chitosan-carboxymethyl cellulose containing zinc oxide nano particles. Int. J. Biol. Macromol. 2017, 99, 530-538. [CrossRef]

32. Zhang, H.; Hortal, M.; Jordá-Beneyto, M.; Rosa, E.; Lara-Lledo, M.; Lorente, I. ZnO-PLA nanocomposite coated paper for antimicrobial packaging application. LWT - Food Sci. Technol. 2017, 78, 250-257. [CrossRef]

33. Mohammadi, H.; Kamkar, A.; Misaghi, A.; Zunabovic-Pichler, M.; Fatehi, S. Nanocomposite films with CMC, okra mucilage, and ZnO nanoparticles: Extending the shelf-life of chicken breast meat. Food Packag. Shelf Life 2019, 21, 100330. [CrossRef]

34. Arfat, Y.A.; Benjakul, S.; Prodpran, T.; Sumpavapol, P.; Songtipya, P. Properties and antimicrobial activity of fish protein isolate/fish skin gelatin film containing basil leaf essential oil and zinc oxide nanoparticles. Food Hydrocoll. 2014, 41, 265-273. [CrossRef]

35. Ejaz, M.; Arfat, Y.A.; Mulla, M.; Ahmed, J. Zinc oxide nanorods/clove essential oil incorporated Type B gelatin composite films and its applicability for shrimp packaging. Food Packag. Shelf Life 2018, 15, 113-121. [CrossRef]

36. Fidelis, M.; de Moura, C.; Junior, T.K.; Pap, N.; Mattila, P.; Mäkinen, S.; Putnik, P.; Kovačević, D.B.; Tian, Y.; Yang, B. Granato Fruit Seeds as Sources of Bioactive Compounds: Sustainable Production of High Value-Added Ingredients from By-Products within Circular Economy. Molecules 2019, 24, 3854. [CrossRef]

37. Homrich, A.S.; Galvão, G.; Abadia, L.G.; Carvalho, M.M. The circular economy umbrella: Trends and gaps on integrating pathways. J. Clean. Prod. 2018, 175, 525-543. [CrossRef]

38. Vrhovsek, U.; Rigo, A.; Tonon, D.; Mattivi, F. Quantitation of Polyphenols in Different Apple Varieties. J. Agric. Food Chem. 2004, 52, 6532-6538. [CrossRef]

39. Souza, V.G.L.; Fernando, A.L.; Pires, J.R.A.; Rodrigues, P.F.; Lopes, A.A.S.; Fernandes, F.M.B. Physical properties of chitosan films incorporated with natural antioxidants. Ind. Crops Prod. 2017, 107, 565-572. [CrossRef]

40. Nouri, A.; Yaraki, M.T.; Ghorbanpour, M.; Agarwal, S.; Gupta, V.K. Enhanced Antibacterial effect of chitosan film using Montmorillonite/CuO nanocomposite. Int. J. Biol. Macromol. 2017, 109, 1219-1231. [CrossRef]

41. Ortez, J.H. Disk diffusion testing. In Manual Of Antimicrobial Susceptibility Testing; Coyle, M.B., Ed.; American Society for Microbiology: Washington, DC, USA, 2005; pp. 39-52. 
42. AOAC Official Methods of Analysis of the Association of Official Analytical Chemists, 20th ed.; AOAC: Washington, DC, USA, 2016.

43. ISO 4833-1:2013. Microbiology of the food chain - Horizontal method for the enumeration of microorganisms - Part 1: Colony count at 30 degrees C by the pour plate technique. 2013. Available online: https: //www.iso.org/standard/53728.html (accessed on 27 January 2020).

44. ISO 17410:2019. Microbiology of the food chain - Horizontal method for the enumeration of psychrotrophic microorganisms. 2001. Available online: https://www.iso.org/standard/67437.html (accessed on 27 January 2020).

45. ISO 21528-2:2017. Microbiology of the food chain - Horizontal method for the detection and enumeration of Enterobacteriaceae — Part 2: Colony-count technique. Available online: https://www.iso.org/standard/ 63504.html (accessed on 27 January 2020).

46. Vandecasteele, C.; Block, C.B. Modern Methods for Trace Element Determination; Wiley: Hoboken, NJ, USA, 1997; ISBN 978-0-471-97445-1.

47. Applerot, G.; Lipovsky, A.; Dror, R.; Perkas, N.; Nitzan, Y.; Lubart, R.; Gedanken, A. Enhanced antibacterial activity of nanocrystalline $\mathrm{ZnO}$ due to increased ros-mediated cell injury. Adv. Funct. Mater. 2009, 19, 842-852. [CrossRef]

48. Rahman, P.M.; Mujeeb, V.M.A.; Muraleedharan, K. Flexible chitosan-nano ZnO antimicrobial pouches as a new material for extending the shelf life of raw meat. Int. J. Biol. Macromol. 2017, 97, 382-391. [CrossRef] [PubMed]

49. Altiok, D.; Altiok, E.; Tihminlioglu, F. Physical, antibacterial and antioxidant properties of chitosan films incorporated with thyme oil for potential wound healing applications. J. Mater. Sci. Mater. Med. 2010, 21, 2227-2236. [CrossRef] [PubMed]

50. Siripatrawan, U.; Vitchayakitti, W. Improving functional properties of chitosan films as active food packaging by incorporating with propolis. Food Hydrocoll. 2016, 61, 695-702. [CrossRef]

51. Soares, F.; Pires, A.C.; Camilloto, G.P.; Santiago-Silva, P.; Espitia, P.J.; Silva, W.A. Recent patents on active packaging for food application. Recent Pat. Food. Nutr. Agric. 2009, 1, 171-178. [CrossRef]

52. Shankar, S.; Teng, X.; Li, G.; Rhim, J.W. Preparation, characterization, and antimicrobial activity of gelatin/ZnO nanocomposite films. Food Hydrocoll. 2015, 45, 264-271. [CrossRef]

53. Kolakowska, A.; Bartosz, G. Oxidation of Food Components: An Introduction. In Food Oxidants and Antioxidants Chemical, Biological and Functional Properties; Bartosz, G., Ed.; CRC Press: Boca Raton, FL, USA, 2014; p. 550. ISBN 13: 978-1-4398-8242-9.

54. Petrou, S.; Tsiraki, M.; Giatrakou, V.; Savvaidis, I.N. Chitosan dipping or oregano oil treatments, singly or combined on modified atmosphere packaged chicken breast meat. Int. J. Food Microbiol. 2012, 156, 264-271. [CrossRef]

55. Riaz, A.; Lei, S.; Akhtar, H.M.S.; Wan, P.; Chen, D.; Jabbar, S.; Abid, M.; Hashim, M.M.; Zeng, X. Preparation and characterization of chitosan-based antimicrobial active food packaging film incorporated with apple peel polyphenols. Int. J. Biol. Macromol. 2018, 114, 547-555. [CrossRef]

56. Singleton, V.L.; Orthofer, R.; Lamuela-Raventós, R.M. Analysis of total phenols and other oxidation substrates and antioxidants by means of Folin-ciocalteu. Methods Enzymol. 1999, 299, 152-178.

57. Baek, S.K.; Song, K. Bin Development of Gracilaria vermiculophylla extract films containing zinc oxide nanoparticles and their application in smoked salmon packaging. LWT - Food Sci. Technol. 2018, 89, 269-275. [CrossRef]

58. Panea, B.; Ripoll, G.; González, J.; Fernández-Cuello, Á.; Albertí, P. Effect of nanocomposite packaging containing different proportions of $\mathrm{ZnO}$ and $\mathrm{Ag}$ on chicken breast meat quality. J. Food Eng. 2014, 123, 104-112. [CrossRef]

59. MINOLTA PRECISE COLOR COMMUNICATION: color control from perception to instrumentation; Minolta Co. Ltda.: Tokyo, Japan, 2007; Available online: https://www.konicaminolta.com/instruments/knowledge/color/ pdf/color_communication.pdf (accessed on 27 January 2020).

60. Rojas, M.C.; Brewer, M.S. Effect of Natural Antioxidants on Oxidative Stability of Frozen, Vacuum-Packaged Beef and Pork. J. Food Qual. 2008, 31, 173-188. [CrossRef]

61. Ghaderi-Ghahfarokhi, M.; Barzegar, M.; Sahari, M.A.; Ahmadi Gavlighi, H.; Gardini, F. Chitosan-cinnamon essential oil nano-formulation: Application as a novel additive for controlled release and shelf life extension of beef patties. Int. J. Biol. Macromol. 2017, 102, 19-28. [CrossRef] 
62. Suo, B.; Li, H.; Wang, Y.; Li, Z.; Pan, Z.; Ai, Z. Effects of ZnO nanoparticle-coated packaging film on pork meat quality during cold storage. J. Sci. Food Agric. 2016, 97, 2023-2029. [CrossRef] [PubMed]

63. Barbut, S. Pale, soft, and exudative poultry meat-Reviewing ways to manage at the processing plant. Poult. Sci. 2009, 88, 1506-1512. [CrossRef] [PubMed]

64. De Melo, A.A.M.; Geraldine, R.M.; Silveira, M.F.A.; Lopes, M.C.; Silva, C.; Fernandes, T.H.; Oliveira, A.N. De Microbiological quality and other characteristics of refrigerated chicken meat in contact with cellulose acetate-based film incorporated with rosemary essential oil. Brazilian J. Microbiol. 2012, 1419-1427. [CrossRef]

65. Khulal, U.; Zhao, J.; Hu, W.; Chen, Q. Intelligent evaluation of total volatile basic nitrogen (TVB-N) content in chicken meat by an improved multiple level data fusion model. Sensors Actuators B Chem. 2017, 238, 337-345. [CrossRef]

66. IFT. Chapter 3: Factors that Influence Microbial Growth. Compr. Rev. Food Sci. Food Saf. 2003, 21-32. [CrossRef]

67. Economou, T.; Pournis, N.; Ntzimani, A.; Savvaidis, I.N. Nisin-EDTA treatments and modified atmosphere packaging to increase fresh chicken meat shelf-life. Food Chem. 2009, 114, 1470-1476. [CrossRef]

68. The commision of the european communities COMMISSION REGULATION (EC) No 2073/2005 of 15 November 2005 on microbiological criteria for foodstuffs; Elsevier: Amsterdam, The Netherlands, 2005; Vol. L338, Available online: https://www.fsai.ie/uploadedFiles/Consol_Reg2073_2005.pdf (accessed on 27 January 2020).

69. Emamifar, A.; Kadivar, M.; Shahedi, M.; Soleimanian-Zad, S. Evaluation of nanocomposite packaging containing Ag and $\mathrm{ZnO}$ on shelf life of fresh orange juice. Innov. Food Sci. Emerg. Technol. 2010, 11, 742-748. [CrossRef]

70. Emamifar, A.; Mohammadizadeh, M. Preparation and application of LDPE/ZnO nanocomposites for extending shelf life of fresh strawberries. Food Technol. Biotechnol. 2015, 53, 488-495. [CrossRef]

71. Noshirvani, N.; Ghanbarzadeh, B.; Rezaei Mokarram, R.; Hashemi, M. Novel active packaging based on carboxymethyl cellulose-chitosan-ZnO NPs nanocomposite for increasing the shelf life of bread. Food Packag. Shelf Life 2017, 11, 106-114. [CrossRef]

72. Kanatt, S.R.; Rao, M.S.; Chawla, S.P.; Sharma, A. Active chitosan-polyvinyl alcohol films with natural extracts. Food Hydrocoll. 2012, 29, 290-297. [CrossRef]

73. INSA PortFIR - composition of poultry meat (chicken breast without skin). Available online: http: //portfir.insa.pt/foodcomp/pdf?904 (accessed on 27 January 2020).

74. Bumbudsanpharoke, N.; Ko, S. Nano-Food Packaging: An Overview of Market, Migration Research, and Safety Regulations. J. Food Sci. 2015, 80, R910-R923. [CrossRef]

75. Croteau, M.-N.; Dybowska, A.D.; Luoma, S.N.; Valsami-Jones, E. A novel approach reveals that zinc oxide nanoparticles are bioavailable and toxic after dietary exposures. Nanotoxicology 2011, 5, 79-90. [CrossRef] 